\title{
Evaluation of the Factors Controlling Concentration of Non-Condensable Gases and Their Possible Impact on the Performance of Geothermal Systems: Case Study of Olkaria Wells in the Kenyan Rift Valley
}

\author{
Ruth N. Wamalwa' ${ }^{1}$, Aaron K. Waswa ${ }^{2 *}$, Cristopher N. Nyamai ${ }^{2}$, Josephat Mulwa ${ }^{2}$, \\ Wills J. Ambusso ${ }^{3}$ \\ ${ }^{1}$ Kenya Electricity Generating Company-KenGen, Naivasha, Kenya \\ ${ }^{2}$ Department of Geology, University of Nairobi, Nairobi, Kenya \\ ${ }^{3}$ School of Pure and Applied Sciences, Kenyatta University, Nairobi, Kenya \\ Email: rwamalwa@kengen.co.ke, ”aaronwaswa@gmail.com, ”awaswa@uonbi.ac.ke
}

Received 22 January 2016; accepted 6 March 2016; published 9 March 2016

Copyright (C) 2016 by authors and Scientific Research Publishing Inc.

This work is licensed under the Creative Commons Attribution International License (CC BY). http://creativecommons.org/licenses/by/4.0/

\section{(c) (i) Open Access}

\section{Abstract}

The Olkaria geothermal field is located in the Kenyan Rift valley, about $120 \mathrm{~km}$ from Nairobi. Development of geothermal resources in the Olkaria area, a high temperature field, started in the early 1950s. In the subsequent years numerous expansions have been carried out with additional power plants being installed in Olkaria. These include a binary plant at Olkaria South West (OIkaria III) in 2000, a condensing plant at Olkaria North East (Olkaria II) in 2003, another binary plant at Olkaria North West (Oserian) in 2004 and finally condensing plants in the year 2014 within East production field (EPF) and Olkaria Domes (OD) areas. The total generation from this field is about $730 \mathrm{Mw}$. The study considered samples from 4 producing wells from 3 fields of the Olkaria geothermal area (OW-44 from the Olkaria East, OW-724A from the Olkaria North East, and OW-914 and OW-915 from the Olkaria Domes field). The chemical data were first analyzed using SOLVEQ. This helped in the determination of the equilibrium state of the system, the reservoir temperatures and the total moles to be run through CHILLER. The run CHILLER considered the processes that have been proven to be occurring in the Olkaria field i.e., boiling and condensing processes, fluid-fluid mixing rocks and titration resulting from water-rock interaction. The effects

${ }^{*}$ Corresponding author.

How to cite this paper: Wamalwa, R.N., Waswa, A.K., Nyamai, C.N., Mulwa, J. and Ambusso, W.J. (2016) Evaluation of the Factors Controlling Concentration of Non-Condensable Gases and Their Possible Impact on the Performance of Geothermal Systems: Case Study of Olkaria Wells in the Kenyan Rift Valley. International Journal of Geosciences, 7, 257-279. 
on gas evolution were evaluated based on the resulting recalculated gas pressures. The results indicate that the gas species are not in equilibrium with the mineral assemblages. The CHILLER evaluation shows boiling as the major process leading to the evolution of gases. $0 \mathrm{~W}-44$ had the least gas concentrations, arising from the considered reservoir processes due to degassing, and near surface boiling, besides the removal of $\mathrm{NH}_{3}, \mathrm{H}_{2}$ and $\mathrm{H}_{2} \mathrm{~S}$ are through the reaction with steam condensate. The gas breakout is most likely in $0 \mathrm{~W}-914$ and least in $0 \mathrm{~W}-44$. The study proposes different reservoir management strategies for the different parts of the Olkaria geothermal field. That is by increasing hot reinjection in the eastern sector around well $0 W-44$. The reservoir around $0 \mathrm{~W}-914$ is to be managed by operating the wells at a minimum flow rate (or even to close them) or the use of chemical inhibitors to prevent calcite scaling.

\section{Keywords}

Geothermal Energy, Gases and Their Impact on Well Perfomance, Olkaria Wells, Kenyan Rift Valley

\section{Introduction}

Evaluation of gas concentrations in Olkaria geothermal field revealed that on average gases are the highest in the Domes, intermediate in Northeast production field and lowest in East production field (West JEC [1]). West JEC [1] considered three factors for the variations: 1) $\mathrm{CO}_{2}$ gets added at great depth to Northeast production field and Domes waters as a result of volcanic degassing below these areas, with less input of deep $\mathrm{CO}_{2}$ to the East production field; 2) $\mathrm{CO}_{2}$ addition at depth is similar in all three areas, but waters of the East production field lose $\mathrm{CO}_{2}$ during the onset of boiling in the reservoir such that the $\mathrm{CO}_{2}$ escapes to fumaroles which lie in the west and south of East production field; 3) cap-rock conditions in the Northeast production field and Domes are somewhat more restrictive than in the East production field, leading to more entrapment at shallower levels of $\mathrm{CO}_{2}$ that has been released by boiling. Gases in particular $\mathrm{CO}_{2}, \mathrm{H}_{2} \mathrm{~S}, \mathrm{H}_{2}$ and $\mathrm{CH}_{4}$ are natural components of volcanic geothermal systems like Olkaria (Kenya), Mahanagdong (Philippines) and Nesjavellir, Hellisheidi and Krafla (Iceland) (Arnórsson et al. [2] and Angcoy [3]).

The gas concentration in systems that are unexploited is generally controlled by temperature dependent equilibria with various mineral buffers (Giroud and Arnórsson [4]). This results in variation in gas concentration with temperature. Giroud and Arnórsson [4] have also stated that for geothermal systems with average reservoir temperatures of between $230^{\circ} \mathrm{C}-300^{\circ} \mathrm{C}$, a case of Olkaria, their $\mathrm{CO}_{2}$ buffer is considered to be clinozoisite, prehnite, quartz and calcite whereas that of $\mathrm{H}_{2} \mathrm{~S}$ buffer to be pyrite, pyrrhotite, epidote and prehnite. In highly saline waters, the $\mathrm{H}_{2} \mathrm{~S}$ mineral buffer consists of pyrite, magnetite and hematite. The gas ratios like in the case of $\mathrm{H}_{2} \mathrm{~S} / \mathrm{H}_{2}$ activity ratio correspond closely to equilibrium with the mineral pairs of pyrite/pyrrhotite and pyrite/magnetite that is generally under saturated with respect to the individual minerals. These findings agreed with Karingithi [5] in the study on the Olkaria field which found out that activity of aqueous $\mathrm{H}_{2}$ and $\mathrm{H}_{2} \mathrm{~S}$ gases generally corresponded closely to equilibrium with the mineral buffer pyrite, pyrrhotite, and magnetite. The activities of these two $\left(\mathrm{H}_{2}\right.$ and $\mathrm{H}_{2} \mathrm{~S}$ gases $)$ also corresponded closely to equilibrium with the mineral buffer pyrrhotite, prehnite, epidote and pyrite. $\mathrm{The}_{2} \mathrm{H}_{2} \mathrm{~S} \mathrm{H}_{2}$ activity ratio corresponded closely to equilibrium with the mineral pair pyrite, pyrrhotite and pyrite and magnetite.

The concentration of gases in a geothermal field under exploitation is higher than those of the parent fluid (Akin et al. [6]). The value is frequently in the range $50-300$ and $2-20$ mmoles $/ \mathrm{kg}$ of steam for $\mathrm{CO}_{2}$ and $\mathrm{H}_{2} \mathrm{~S}$ respectively (Giroud and Arnórsson [4]). The variation is dependent on their concentration in the parent geothermal fluid, the steam fraction, the steam separation pressure and the boiling processes. According to Giroud and Arnórsson [4], long-term utilization of geothermal reservoirs can lead to decline in the concentrations of $\mathrm{CO}_{2}$ and $\mathrm{H}_{2} \mathrm{~S}$ in the steam. This decline may be caused by the recharge of cold water into producing aquifers and/or progressive boiling of water retained in the aquifer by capillary forces. Enhanced boiling, which is a consequence of reservoir pressure draw down and steam separation during lateral flow into production wells may cause the well discharge to become depleted in gas. In case of a boiling reservoir, the gas concentrations tend to be higher compared to concentrations at a particular temperature and formation of steam caps in the reservoir and/or enhance fumarolic activity. Karingithi [5] also notes that gas samples from marginal wells whose 
discharge fluid are mixed with non-geothermal fluid show low $\mathrm{H}_{2}$ and $\mathrm{H}_{2} \mathrm{~S}$ values with respect to the equilibrium with the mentioned buffer.

The gases are among the factors that affect the reservoir pressure in the deep liquid-dominated geothermal reservoirs (Haizlip et al. [7]). Haizlip et al. [7] further added that under static conditions, pressure in most producing aquifers around the world ranges between 130 and 230 bars at depths between 1700 and $2800 \mathrm{~m}$. The temperatures in this depths range between $219^{\circ} \mathrm{C}$ and $242^{\circ} \mathrm{C}$. The effect of the gas pressures on a well performance is evaluated in terms of the gas breakout pressure i.e. the pressure below which the fluids begin to transform into two-phase. According to Haizlip et al. [7] gas breakout pressure is the sum of the gas pressure and water pressure at the reservoir temperature. In most cases, due to pressure drop, thermal fluids start to boil leading to degassing of $\mathrm{CO}_{2}$ while fluids rise in a wellbore. In bicarbonate type of waters, this leads to the fluid becoming saturated with calcite as a reaction between $\mathrm{CO}_{2}$ and calcium.

For a field that is under utilization like Olkaria, changes in the gas content of well discharges with time help in providing valuable information about the response of the reservoir to the production load (Karingithi [5]). This is in respect with processes such as cold recharge resulting to fluid-fluid mixing, volcanic degassing and enhanced boiling (Gudmundsson and Arnórsson [8]; Armannsson [9]). In this study an evaluation of reaction processes controlling the concentration of prevalent reactive gases $\mathrm{CO}_{2}, \mathrm{H}_{2} \mathrm{~S}, \mathrm{H}_{2}, \mathrm{CH}_{4}$ and $\mathrm{N}_{2}$ in Olkaria well discharges are determined. The procedure involve first the determination of the equilibrium state between fluids and rocks using the software package SOLVEQ followed by determination of reaction processes in aqueous-mineral-gas systems using the software package CHILLER (Reed et al. [10] [11]). The software package SOLVEQ/CHILLER, have been preferred due to its applicability for studying multiphase systems as well undergo boiling and mixing processes (Bienkowski et al. [12]). This issue is relevant for the long-term release of gases from geothermal power plants. This is with the purpose of predicting possible decline in gas emissions. Then the results are evaluated against the measured pressures through the downhole temperature and pressure surveys to determine if there are chances of gas breakout occurrence.

\section{Geographical Setting of the Study Area}

The Olkaria Geothermal area is located within the Olkaria central volcanic complex in the central sector of the Kenyan Rift Valley. The complex is located south of Lake Naivasha, approximately $120 \mathrm{~km}$ from the capital city Nairobi. It is bordered by other geothermal prospect areas, like Suswa, Longonot and Eburru (Figure 1).

This geothermal area covers approximately $140 \mathrm{~km}^{2}$ and is divided into seven fields: Olkaria East, Olkaria Northeast, Olkaria Central, Olkaria Northwest, Olkaria Southwest, Olkaria Southeast, and Olkaria Domes for ease of exploitation (Figure 2). The fields are in different stages of exploitation. The completely explored fields are Olkaria East, Olkaria Northeast and Olkaria Southwest while Olkaria-Domes is the recent of them all where exploitation for power production started in the year 2014 whereas Olkaria Southwest is yet to be developed.

The Olkaria East Field is located on the East of the Olkaria hill (Figure 3) and has been under steam exploitation since 1985 through the Olkaria 1 power plant. This power plant is served by 31 wells connected to the steam gathering system. As of end of 2014, the steam was being harnessed from 22 as 9 wells had become non-commercial producers due to decline in output over time. Two of these wells, OW-6 and OW-3 are being used as reinjection wells whereas OW-11 was recently commissioned to take low pressure (LP) brine from OW-2, 27, 31 and 33 in March 2015. The field also hosts newly drilled wells like OW-35, OW-36A, OW-37A, OW-38, OW-38A, OW-41, OW-42A and OW-44, OW-44A and OW-44B for the Olkaria1 unit IV and V power plant. This power plant was commissioned in October 2014. OW-37A, OW-43 and OW-43A are connected to wellhead generators.

The Olkaria North East field has been used for power generation since October 2003. It has a total of 20 wells that are connected to the steam gathering system. Of the twenty, 6 wells (OW-709, OW-710, OW-712, OW-713, OW-718 and OW-721) have individual separators while the other 14 wells (OW-701, OW-727, OW-705, OW-725, OW-706, OW- 711, OW-707, OW-715, OW-714, OW-716, OW-719, OW-726, OW-720 and OW-728) share separators. Four wells are used for hot re-injection i.e., OW-R2, OW-R3, OW-703 and OW-708. Wells OW-704, OW-717, OW-723 and OW-724 are non-producers and are currently used for pressure monitoring (Figure 2).

Olkaria-Domes Field lies in the west of Longonot Volcano and on the SE of the Olkaria hill (Figure 3). It was the last of the 7 sectors to be explored by deep drilling. Here, three deep exploration wells were drilled between 


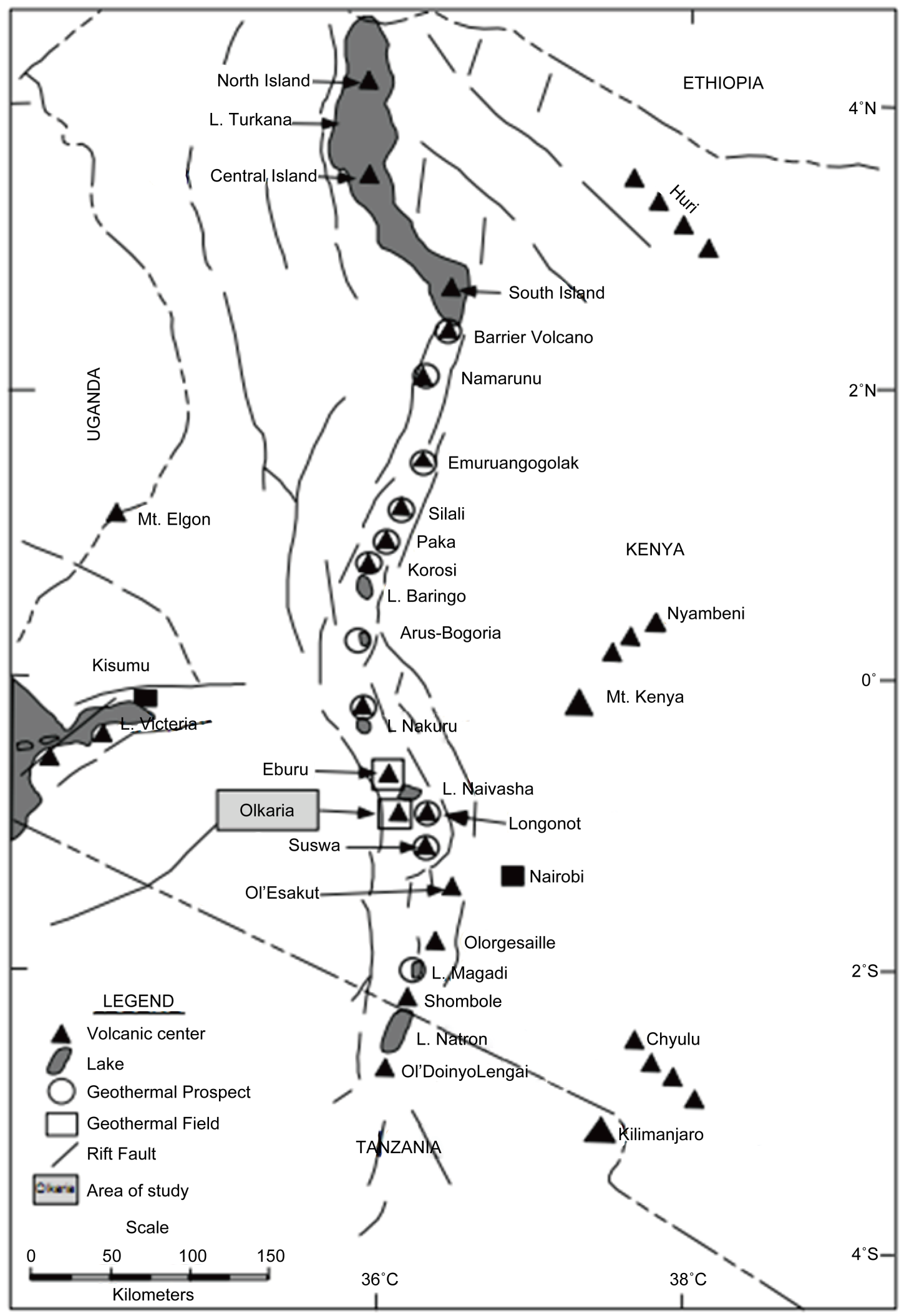

Figure 1. Map of the Kenya rift showing the location of Olkaria geothermal field and other Quaternary volcanoes along the rift valley (Lagat [13]). 


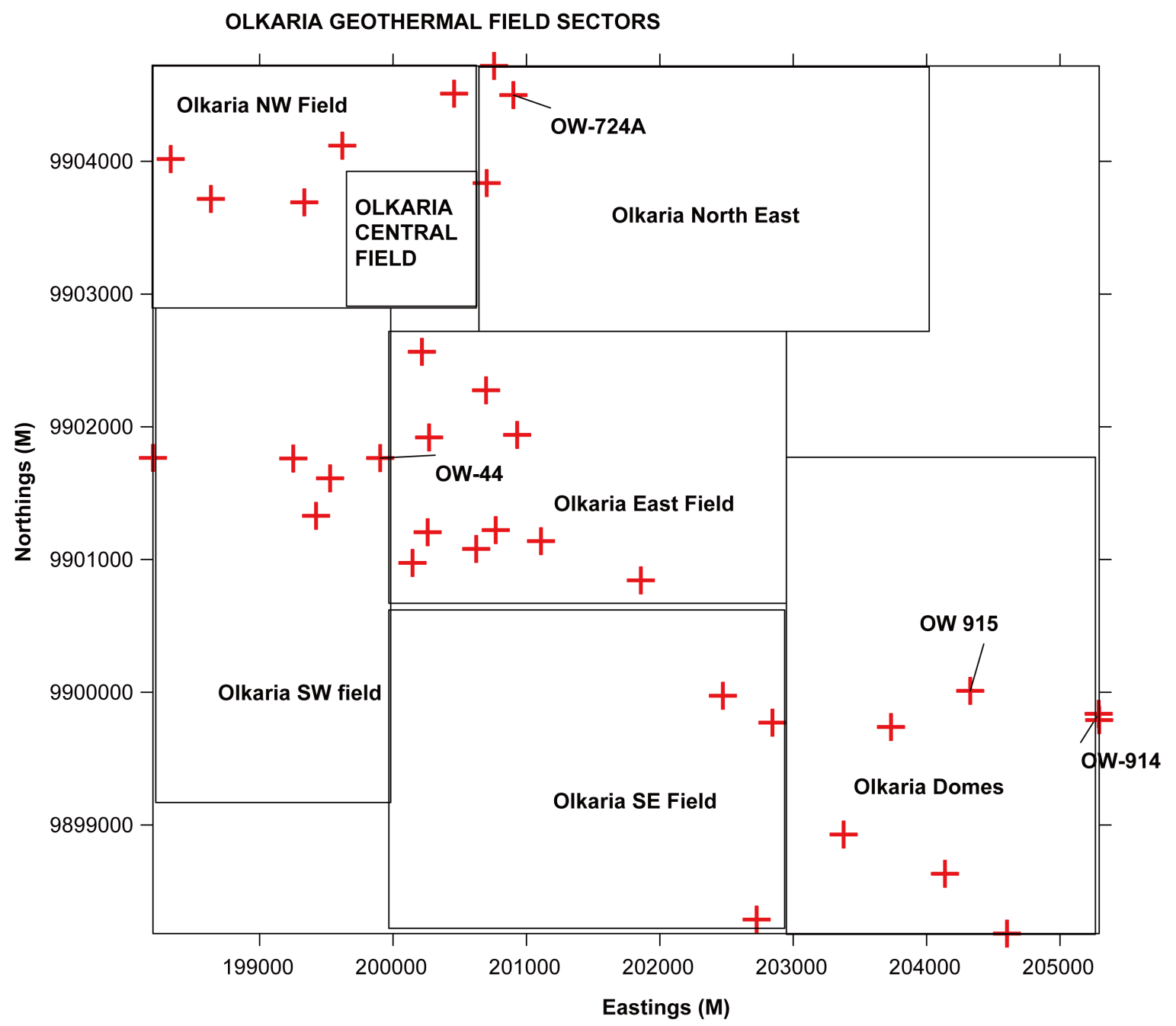

Figure 2. Geothermal fields within the Greater Olkaria geothermal area (KenGen [14]). The red crosses indicate the location of wells. Labeled wells are the ones used in this study.

1998 and 1999. Drilling was halted for close to eight years due to shortage of funding but resumed in June 2007. This led to realization of $140 \mathrm{MWe}$ power plant commissioned in October, 2014 using wells OW-910, OW910A, OW-910B, OW-908, OW-908A, OW-908B and OW-909, OW-915, OW-915A, OW-915B, OW-916 and OW-912.

\subsection{Geological Features and Physical Characteristics of the Reservoir}

\subsubsection{Geology of Olkaria Volcanic Complex}

Olkaria volcanic complex does not have a clear caldera association (Naylor [15]; Virkir [16]; Clarke et al. [17]; Mungania [18]). However, Lagat et al. [13] concluded that the presence of a ring of domes in the east and south, and southwest can be used to infer to the presence of a buried caldera. The downhole geology in geothermal wells in Olkaria field has helped to reveal the lithostratigraphy of the area (Omenda [19]). From this study, the regional geology has been divided into six main lithostratigraphy groups: proterozoic "basement" formations, pre-Mau volcanics, Mau tuffs, plateau trachytes, Olkaria basalt and Upper Olkaria volcanics. The basement rocks comprise of Proterozoic amphibolite facies grade gneisses, schists, marble and quartzites of the Mozambique group (Shackleton [20]; Smith and Mosley [21]). The Mau tuffs are the oldest which outcrop on the surface in the Olkaria area. Omenda [19] [22] concluded that this might be due to an east dipping high angle normal fault that is cutting through the Olkaria Hill. The Upper Olkaria volcanic are overlain by Olkaria basalt in 


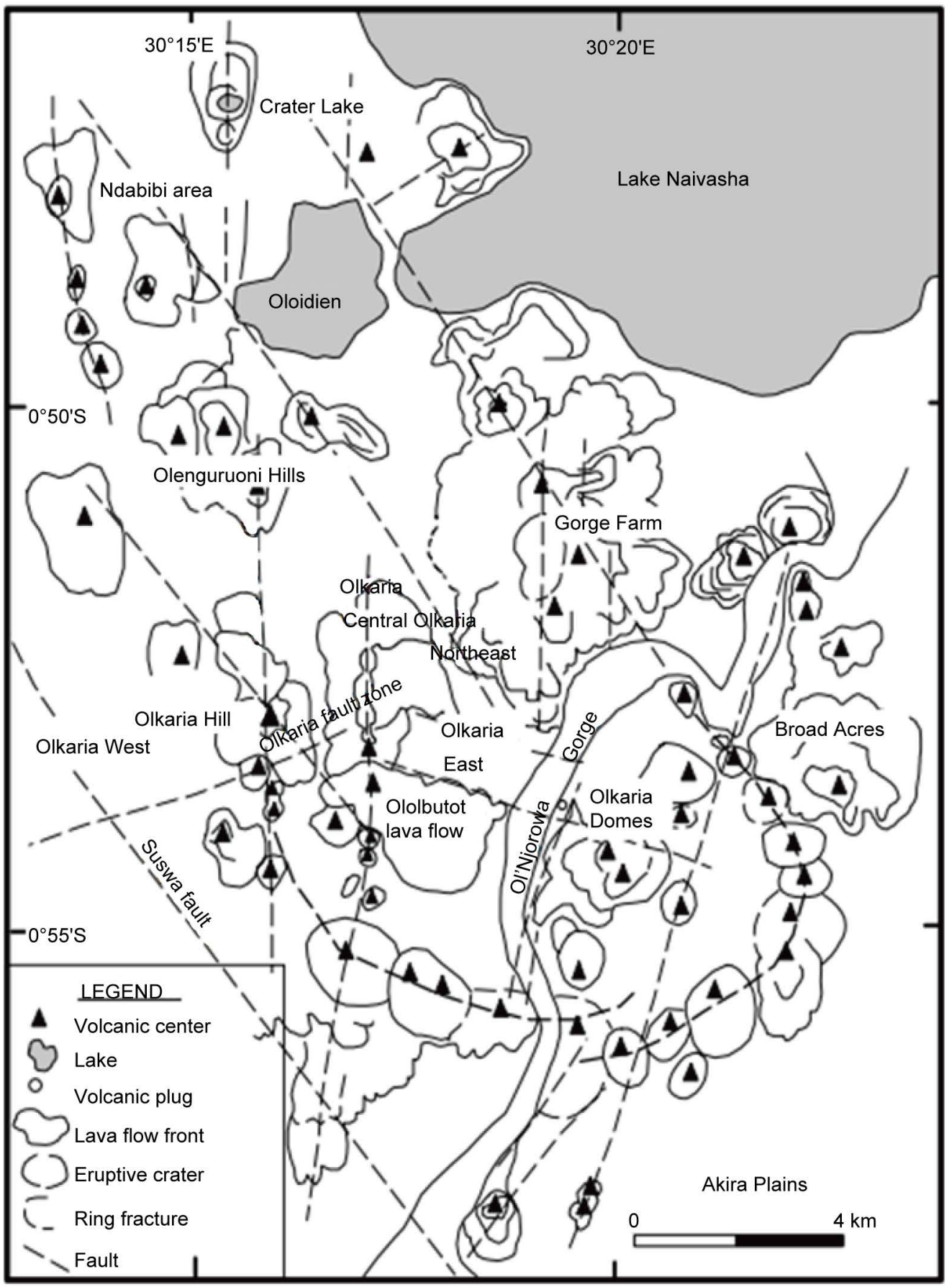

Figure 3. Volcano-tectonic map of the Greater Olkaria volcanic complex (modified after Clarke et al. 1990).

the area to the east of Olkaria Hill while the formation is absent to the west. This formation consists of basalt flows and minor pyroclastics and trachytes and varies in thickness from $100 \mathrm{~m}$ to $500 \mathrm{~m}$ (Omenda [22]). The Upper Olkaria formations comprise of mainly lavas and ashes from Suswa and Longonot volcanoes (Thompson et al. [23]; Ogoso-Odongo [24]; Clarke et al. [17]; Omenda [22]).

\subsubsection{Structural Setting of the Olkaria Volcanic Complex}

Structures in the Olkaria geothermal area include the ring structure, the Ol'Njorowa gorge, the Gorge Farm 
fault, the ENE-WSW Olkaria fault and NW-SE trending faults (Figure 3). Faults are prominent in the East, Northeast and West Olkaria fields unlike in the Olkaria Domes area, most probably due to the thick pyroclastics cover in this area (Clarke et al. [17]). The NW-SE trending faults are thought to be the oldest and are associated with the development of the rift and are associated with hot chloride rich fluids except for the Gorge farm fault, which bounds the geothermal fields in the north eastern part and extends to the Olkaria Domes area. The most recent structures are the NNE-SSW faults. They are thought to be young and carry cold, low chloride fluids.

The northern edge of the Olkaria Domes has volcanic domes, which occur in submerged country (Mungania [18]). These craters are arranged along a row where the extrapolated caldera rim trace passes. Dike swarms exposed in the Ol'Njorowa gorge trend in a NNE direction further confirming the reactivation of recent faults with this trend. The development of the Ol'Njorowa gorge is thought to have been initiated by faulting along the trend of the gorge but the feature as it is today resulted from catastrophic outflow of Lake Naivasha during its high stands (Clarke et al. [17]).

The volcanic plugs (necks) and felsic dikes occurring along the gorge further contributes to the evidence that the fault controls the development of this feature. Subsurface faults have been encountered in most Olkaria wells (KenGen [14]). This is witnessed mostly in wells that encountered drilling problems when these faults were dissected due to collapse and loss of drilling fluids and cement. Materials recovered from these zones were mainly fault breccias.

\section{Reservoir Characteristics}

\subsection{Reservoir Pressure and Temperature Characteristics}

Studies on the temperature and pressure distribution in the entire field indicate that fluid movement in the Olkaria geothermal system is tectonically controlled (Ofwona [25]). The reservoir temperatures reach as high as $380^{\circ} \mathrm{C}$ at 3400 meters depth in well OW-49 in Olkaria East. The Olkaria East and North East have a two-phase reservoir (reservoir has steam water mixture feed zone) at least to the depth penetrated by the deepest wells whereas the Olkaria Domes has a liquid dominated reservoir without a steam cap (Ambusso and Ouma [26]; KenGen [14]). The pressure decreases both eastwards and westwards from respective peaks towards Olkaria Central (Figure 4). Within the Olkaria Central and Northeast, the pressures decline southwards towards well OW-401 and towards Olkaria East, respectively (Ouma [27]).

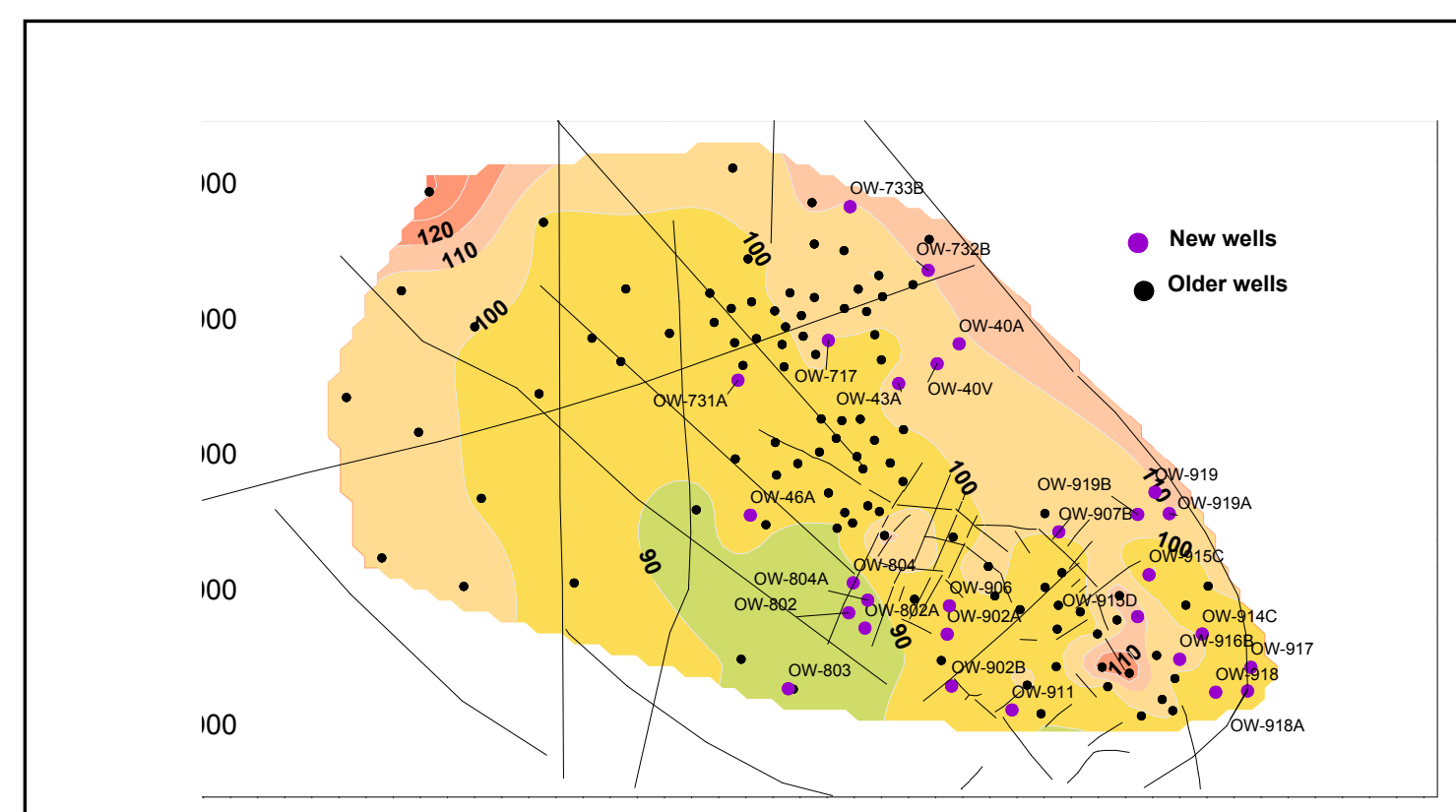

Figure 4. Measured Pressure variations for the Olkaria geothermal field. 
On the individual wells of interest, as shown in profiles in Figure 5, OW-44 was drilled to $3000 \mathrm{~m}$ in early 2011. It has a high injectivity index $164 \mathrm{lpm} / \mathrm{bar}$ and bottom hole temperatures of about $300^{\circ} \mathrm{C}$. Major feed zones are observed at around $760 \mathrm{~m}$ and $2250 \mathrm{~m}$ while minor ones at $1500 \mathrm{~m}$ and $1750 \mathrm{~m}$ depths. OW-724A just
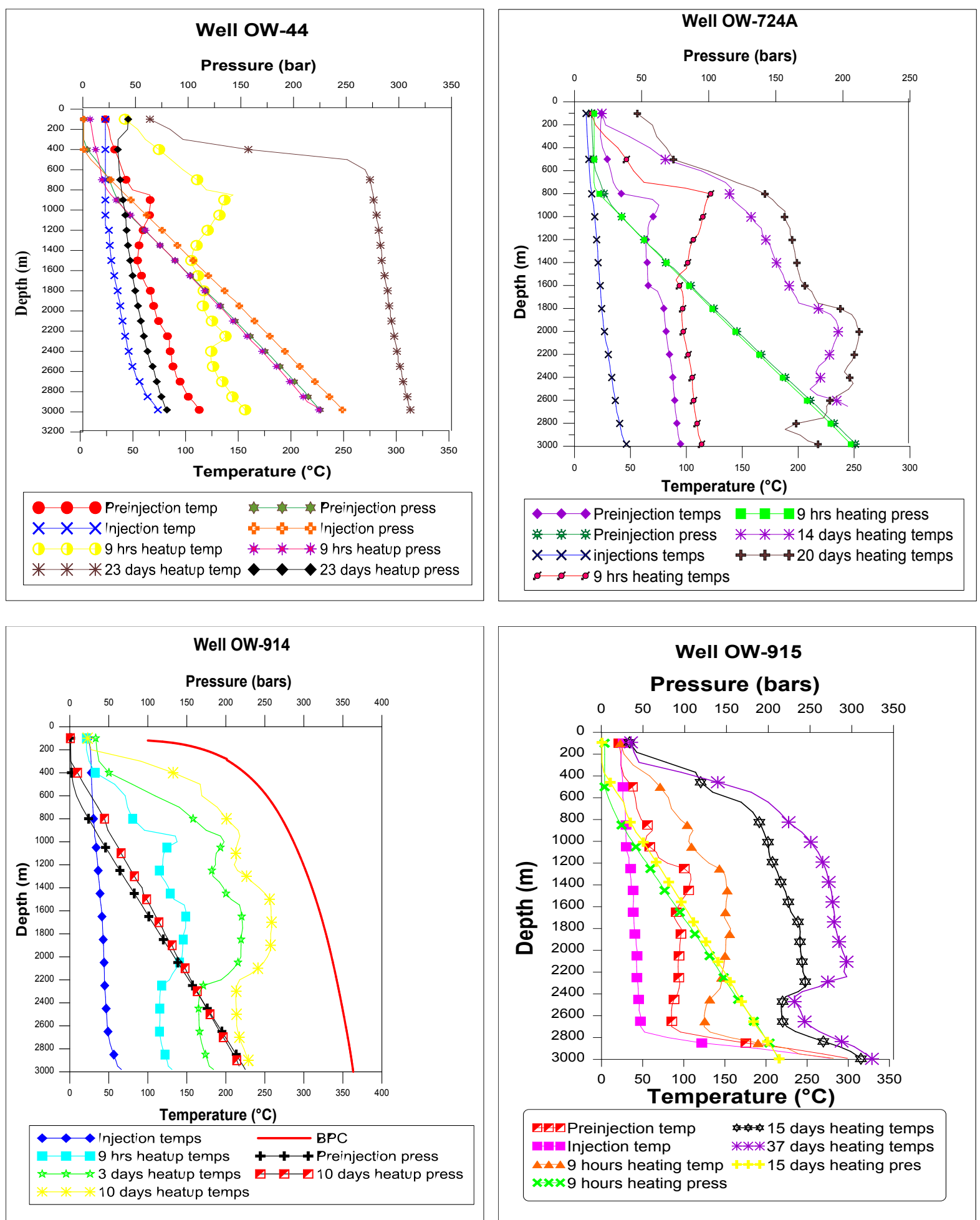

Figure 5. OW-44, OW-724, OW-914 and OW-915 downhole temperature and pressure profiles BPC stands for boiling point curve. 
like OW-44 was drilled to a depth of $3000 \mathrm{~m}$ but in early 2012. It has slightly higher injectivity than OW-44 at about $180 \mathrm{lpm} / \mathrm{bar}$. The major feed zone in this well is at $1800 \mathrm{~m}$ and minor ones are observed at $1400 \mathrm{~m}, 1750$ $\mathrm{m}, 2000 \mathrm{~m}$, and $2550 \mathrm{~m}$ depths as indicated by the heat up temperature profiles. The pressure profiles indicate that the water rest level was at $550 \mathrm{~m}$ during pre-injection. There is a pivot point at around $1800 \mathrm{~m}$ depth hence the major feed zone is around $1800 \mathrm{~m}$ depth. The pressure profiles indicate that the water rest level was at $550 \mathrm{~m}$ during pre-injection.

OW-915's (in the Olkaria Domes field) temperature profile plot indicates minor feed zone between $1200 \mathrm{~m}$ and $1500 \mathrm{~m}$ and a major feed zone at $2300 \mathrm{~m}$ meters depth. The pre-injection data shows a water rest level at approximately $300 \mathrm{~m}$ depth. The well has low injectivity compared to OW-44 and OW-724A at $145 \mathrm{lpm} / \mathrm{bar}$.

\subsection{Reservoir Fluid Chemistry}

The Olkaria wells discharge fluids with enthalpy ranging from $1000 \mathrm{~kJ} / \mathrm{kg}$ to $2750 \mathrm{~kJ} / \mathrm{kg}$ (Karingithi [5]). Wells in the east production field have excess discharge enthalpy. This implies that the enthalpy of discharged fluid is higher than that of steam-saturated water at the respective aquifer temperatures.

The water discharged from wells in the Olkaria field is low in dissolved solids compared to fluids from most other drilled high-temperature geothermal fields in the world with chloride concentrations in liquid ranges between 50 and 1100 ppm (Karingithi [28]). The water from wells in Olkaria East and Northeast (Figure 2) tend to be highest in chloride at about $1000 \mathrm{ppm}$. According to Karingithi [5] the high chloride could be as a result of up flow of deep high-temperature geothermal fluid, although progressive boiling by heat flow from the rock may also be a contributing factor.

A study by Wambugu [29] established that in Olkaria West field the chloride concentrations are quite low of about 350 ppm except in well OW-305, which discharges water similar to that discharged from the wells in the Olkaria East and Olkaria Northeast fields. Well OW-305 is therefore thought to be tapping of the up-flow fluid for Olkaria West field. The relative abundance of chloride, sulfate and bicarbonate plots show that wells in the Olkaria East production field and in Olkaria Northeast discharge sodium-chloride type water while the Olkaria Domes fields discharge a mixture of chloride and bicarbonate end-member water (Figure 6) (Ken Gen [30]). The liquid from Olkaria wells is slightly to moderately alkaline $\left(\mathrm{pH} 8.1-9.9\right.$ as measured at $\left.20^{\circ} \mathrm{C}\right)$ and is relatively high in bicarbonate (Wambugu [29]). The bicarbonate concentration is in the range of with $90-13000$ ppm with distinctly highest carbon dioxide found in the Olkaria West field followed by the Olkaria Domes.

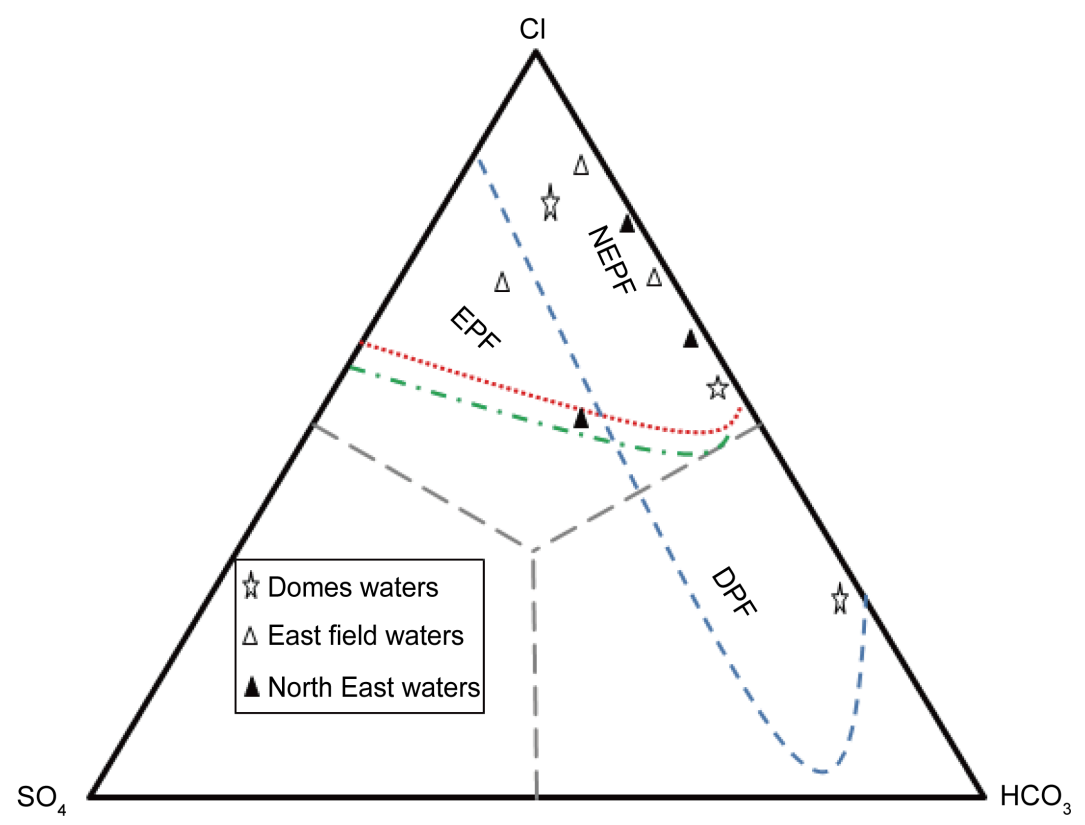

Figure 6. $\mathrm{Cl}-\mathrm{SO}_{4}-\mathrm{HCO}_{3}$ ternary for the Olkaria geothermal field. FPF stands for East production field, NEPF for North East production field while DPF for Domes production field. 
Wambugu [29] added that this could be a consequence of $\mathrm{CO}_{2}$ supply to the geothermal fluid and a subsequent reaction between the carbonic acid and minerals of the rock leading to evolution of $\mathrm{CO}_{2}$ gas.

\subsection{Geochemical Conceptual Model}

The geochemical data identifies upflow zones in the areas around OW-701, OW-711 and OW-705 in the Olkaria North East field, OW-38, OW-32, OW-35A and OW-39A for the Olkaria East field and in the Olkaria Domes area in wells OW-908, OW-908A and OW-911A (Figure 7). These areas are characterized by chloride dominated fluids. Areas around OW-914 and OW-902 have peripheral waters and thus thought to be on the margins of the reservoir.

The influence of structures is also apparent with the NW-SE trending faults being associated with high temperature and $\mathrm{Cl}$ rich waters. The NE-SW trending faults tend to carry cold waters that have led to decline in enthalpies of the wells like OW-719, OW-32 and OW-16 where they cuts through (Wamalwa et al. [31]). Wamalwa et al. (2014) added that the faults within the Ol Njorowa gorge (between the Olkaria East and Olkaria Domes) act to carry cold, less mineralized water that tend to dilute the wells in the shallow depths as in the case of OW-21, OW-22 and OW-23.

\section{Methodology}

\subsection{Sampling and Analysis}

The study comprises samples from 4 producing wells of 3 fields out of 7 in the Olkaria geothermal area (Table 1). The sampling and analysis was carried out by KenGen staff using methods as described by (Arnórsson et al. [32]; Stefansson et al. [33]). The liquid and vapour phase were separated using a Webre separator connected to the pipe line. Here, care was made to ensure that no condensation occurred upon cooling from the pipe line into and out of the separator. After the set up, vapour samples were collected into pre-evacuated gas bulbs (100 ml) containing $40 \% \mathrm{NaOH} . \mathrm{CO}_{2}$ and $\mathrm{H}_{2} \mathrm{~S}$ were absorbed in the $\mathrm{NaOH}$ solution whereas the non-condensable gases i.e., $\mathrm{H}_{2}, \mathrm{~N}_{2}, \mathrm{O}_{2}$, $\mathrm{Ar}$ and $\mathrm{CH}_{4}$ got concentrated within the gas-head space of the gas bulb. The non-condensable gases

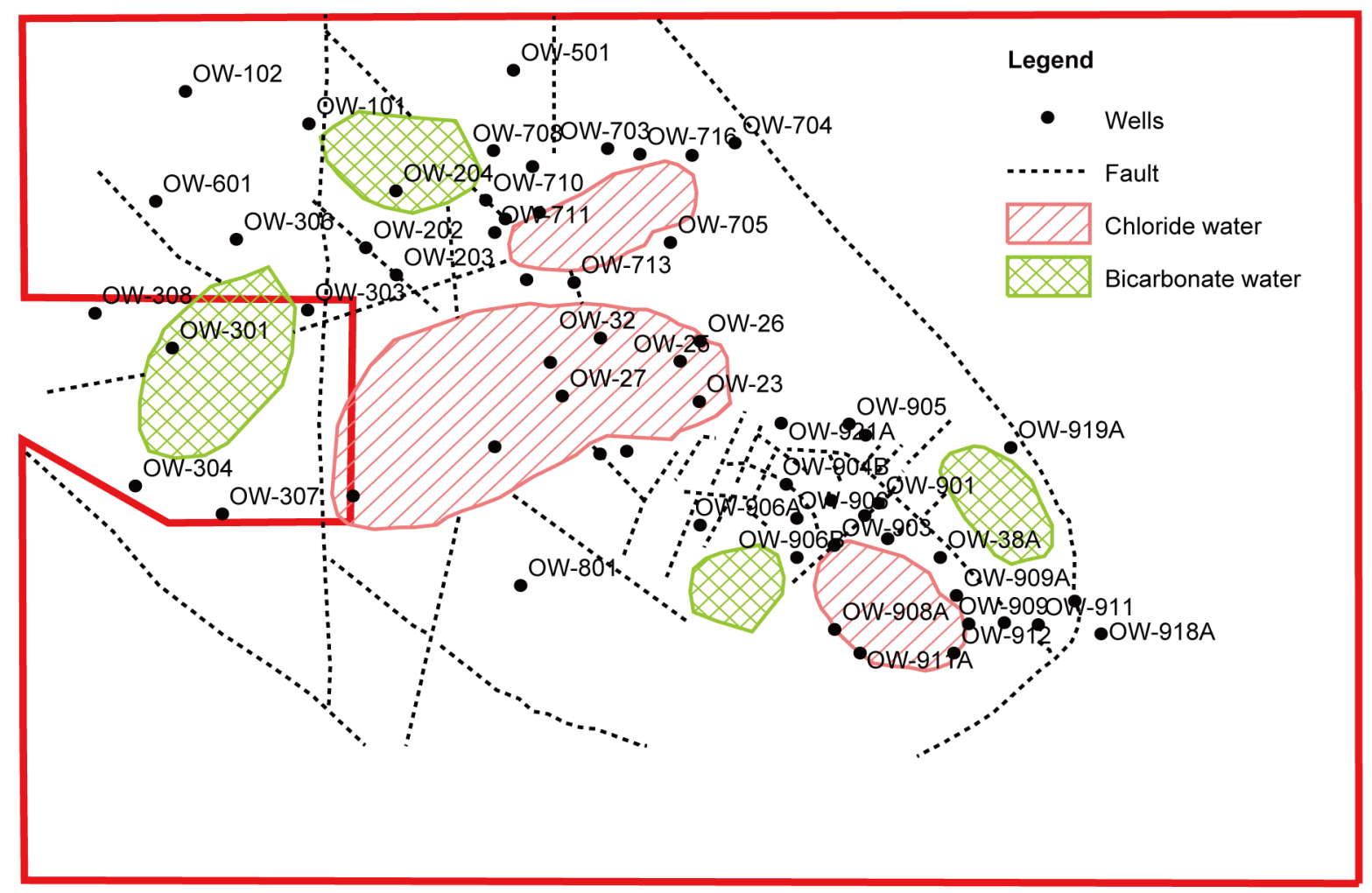

Figure 7. Distribution of the various water types in the Olkaria geothermal area (Ken Gen [30]). 
Table 1. Geochemical data from the studied wells.

\begin{tabular}{|c|c|c|c|c|}
\hline & OW-44 & OW-724A & OW-914 & OW-915 \\
\hline WHP (bar-g) & 14 & 10 & 11 & 11.58 \\
\hline SP (bar-g) & 14 & 9 & 10 & 10 \\
\hline $\mathrm{pH}$ at $20^{\circ} \mathrm{C}$ & 7.91 & 9.43 & 9.91 & 9.93 \\
\hline Enthalpy $(\mathrm{KJ} / \mathrm{Kg})$ & 2500 & 1698 & 2111 & 2034 \\
\hline Cond $(\mu \Omega / \mathrm{cm})$ & 6130 & 2770 & 7482 & 2690 \\
\hline TDS (ppm) & 3064 & 1660 & 3742 & 1345 \\
\hline $\mathrm{SiO}_{2}(\mathrm{ppm})$ & 487 & 610 & 636 & 682 \\
\hline $\mathrm{B}(\mathrm{ppm})$ & 14.41 & 3.783 & 2.37 & 3.17 \\
\hline $\mathrm{Cl}(\mathrm{ppm})$ & 1203 & 452.7 & 431.54 & 480.64 \\
\hline $\mathrm{F}(\mathrm{ppm})$ & 79 & 35.8 & 244.28 & 187.41 \\
\hline $\mathrm{SO}_{4}(\mathrm{ppm})$ & 143.1 & 201.6 & 68.5 & 16.1 \\
\hline $\mathrm{CO}_{2}(\mathrm{ppm})$ & 88.22 & 321.86 & 1520.6 & 246.62 \\
\hline $\mathrm{H}_{2} \mathrm{~S}$ (ppm) & 0.15 & 7.14 & 6.3 & 17.88 \\
\hline Li (ppm) & 1.83 & 1.42 & 2.547 & 0.671 \\
\hline $\mathrm{Na}(\mathrm{ppm})$ & 827 & 508.7 & 1455 & 653.5 \\
\hline $\mathrm{K}(\mathrm{ppm})$ & 245.9 & 70.95 & 445.9 & 189.8 \\
\hline $\mathrm{Ca}(\mathrm{ppm})$ & 1.266 & 2.159 & 0.01 & 2.672 \\
\hline $\mathrm{Mg}(\mathrm{ppm})$ & 0.54 & 0.033 & 1.282 & 0.047 \\
\hline $\mathrm{Fe}(\mathrm{ppm})$ & 1.37 & 0.265 & 1.35 & 1.35 \\
\hline $\mathrm{CO}_{2}\left(\mathrm{mmol} / 100\right.$ moles $\left.\cdot \mathrm{H}_{2} \mathrm{O}\right)$ & 88.4 & 261.3 & 498.1 & 329.8 \\
\hline $\mathrm{H}_{2} \mathrm{~S}\left(\mathrm{mmol} / 100\right.$ moles $\left.\cdot \mathrm{H}_{2} \mathrm{O}\right)$ & 10.26 & 4.66 & 0.91 & 5.03 \\
\hline $\mathrm{CH}_{4}\left(\mathrm{mmol} / 100\right.$ moles $\left.\cdot \mathrm{H}_{2} \mathrm{O}\right)$ & 0.29 & 0.03 & 0.61 & 0.25 \\
\hline $\mathrm{H}_{2}\left(\mathrm{mmol} / 100\right.$ moles $\left.\cdot \mathrm{H}_{2} \mathrm{O}\right)$ & 12.91 & 9.62 & 12.26 & 19.5 \\
\hline $\mathrm{N}_{2}\left(\mathrm{mmol} / 100\right.$ moles $\left.\cdot \mathrm{H}_{2} \mathrm{O}\right)$ & 21.21 & 12.15 & 18.05 & 2.58 \\
\hline $\mathrm{O}_{2}\left(\mathrm{mmol} / 100 \mathrm{moles} \cdot \mathrm{H}_{2} \mathrm{O}\right)$ & 0 & 0 & 0 & 0.35 \\
\hline
\end{tabular}

$\mathrm{WHP}=$ well head pressure; $\mathrm{SP}=$ sampling pressures.

were then analyzed within the head space of the gas bulbs using gas chromatography (GC) while the concentrations of $\mathrm{CO}_{2}$ and $\mathrm{H}_{2} \mathrm{~S}$ were analyzed within the alkaline condensate by titration. The liquid phase samples were cooled down using a stainless steel spiral that was connected to the Webre separator in-line and immersed in a bucket of water. Samples for major cation determination were filtered through $0.2 \mu \mathrm{m}$ filters into polypropylene bottles and acidified with $0.5 \% \mathrm{HNO}_{3}$ and later analyzed using an ion chromatography photometer (ICP). Samples for major anion and $\mathrm{CO}_{2}$ determination were filtered through $0.2 \mu \mathrm{m}$ filters into polypropylene and amber glass bottles and analyzed using ion chromatography (IC). The quality of the sampling and chemical analysis was ensured by using well-known standard solutions for calibration, running reference samples before starting the analysis and evaluation of charge balance for the analyses. The samples used had a charge balance between $-5 \%$ and $+5 \%$.

\subsection{Data Analysis}

The chemical data was first run through SOLVEQ to determine the equilibrium state of the system and then through CHILLER considering the processes that have been proven to be occurring in the most high temperature geothermal fields (Reed et al. [10]). These processes include boiling and condensing processes, fluid-fluid mix- 
ing and rocks titration (hydrothermal alteration of the mineralogy of a well as a result of hot fluids and rocks interaction). Their effect on the evolution of gases is by looking at the resulting recalculated gas pressures.

\subsubsection{Equilibrium Evaluation}

The equilibrium constants were determined using mineral assemblages that potentially controlled the concentrations of $\mathrm{H}_{2} \mathrm{~S}, \mathrm{H}_{2}$ and $\mathrm{CO}_{2}$ in the aquifer fluid using reactions as shown in Table 2 and temperature equations for the equilibrium constants in Table 3. These included thermodynamic data on oxide and silicate minerals as given by Holland and Powell [34] whereas sulfide minerals were as reported by Robie and Hemingway [35]. The thermodynamic properties of the dissolved gases were based on the solubility constants by Fernandez-Prini et al. [36] and the standard Gibbs energies of the ideal gases given by Robie and Hemingway [35]. Over the limited pressure range considered, the specific volume of minerals was taken to be independent of temperature and pressure.

Activities of end-members in the epidote (epidote and clinozoisite), garnet (grossular and andradite) and prehnite (Al-prehnite and Fe-prehnite) solid solutions were used. The values were 0.8 and 0.2 for Epidote and clinozoisite respectively as well as for $\mathrm{Al}$ and $\mathrm{Fe}$-prehnite. Other minerals were taken to have unit activity.

\subsubsection{Evaluation of Gas Concentrations versus the Reservoir Processes}

\section{a. Gas concentrations as a result of boiling and condensing processes}

The calculations were done according to Reeds et al. [10] [11]. This was done by inputting the reservoir temperatures as recorded from SOLVEQ run. CHILLER was run at the specified reservoir temperatures TEMP and a set limit SLIM so that no temperature increments takes place. The fluid pressures (PFLUID) in the pickup

Table 2. Reaction equations for the equilibrium constants (Arnórsson et al. 2010).

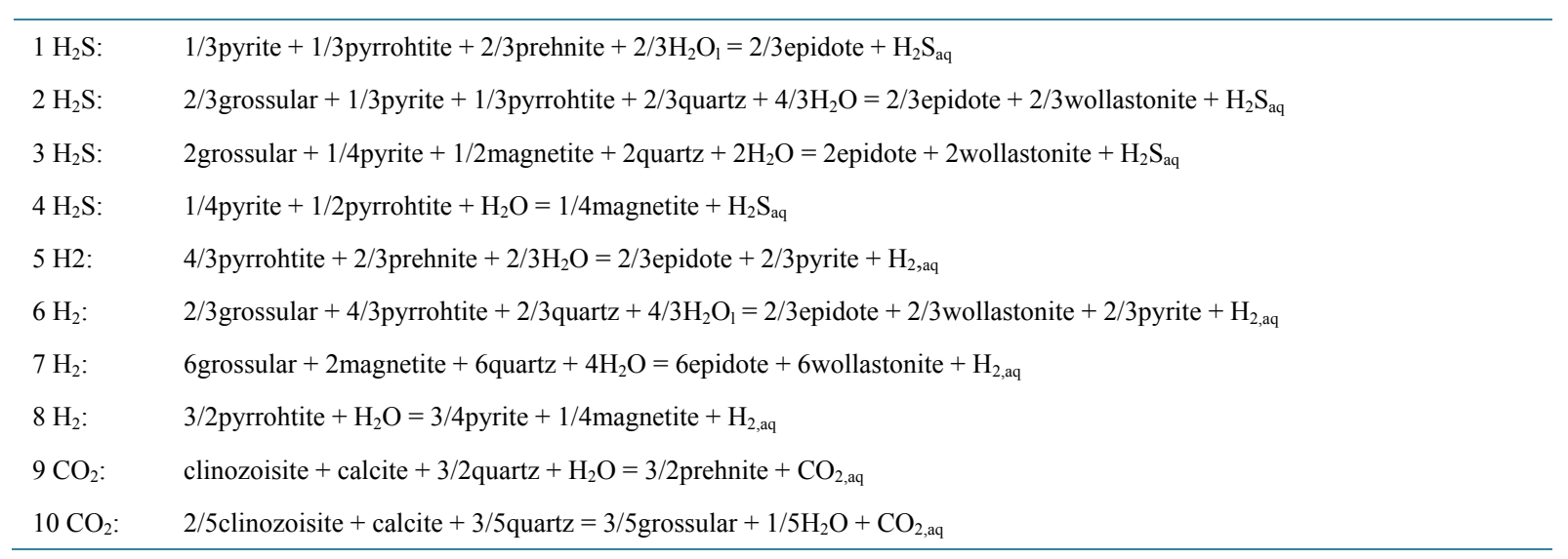

Table 3. Log K-temperature equations for the reactions given in Table 2 above (Arnórsson et al. 2010)

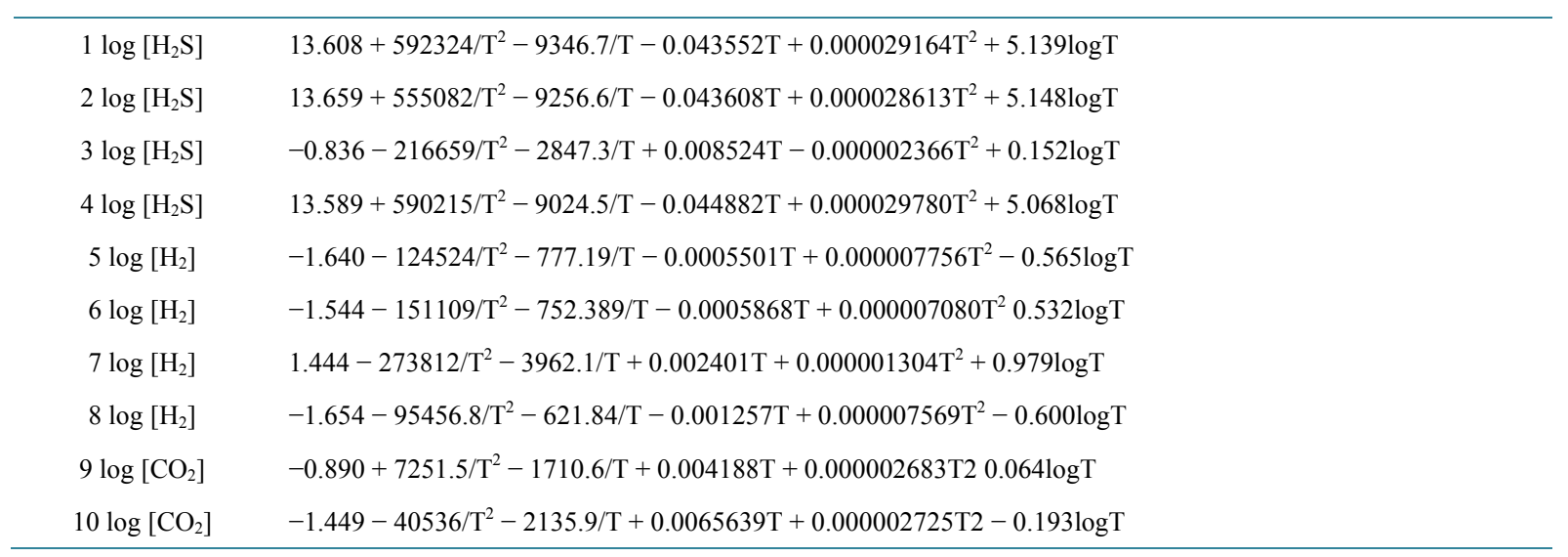

$\mathrm{T}=$ Temperature in kelvin. 
file was set lower than the saturation pressures while the temperature increments (STEP INCREM) for temperatures were set to -10 (decreasing temperatures). It must be noted that the oversaturated minerals as read out in SOLVEQ were suppressed to minimize their masking of the convergence of the equations. CHILLER was then allowed to execute. The programme equilibrated with the gas phase and started boiling following STEP INCREM temperature drop and adjusted PFLUID. Considering that the enthalpy (ENTH) was set at zero, CHILLER sets the current ENTH to be equal to the enthalpy of the aqueous phase at the given temperature. To ensure that the boiling remained iso-enthalpic, the starting total enthalpy SENTH was set at zero, CHIM sets SENTH equal to the current total enthalpy ENTH. From the output (CHIMOUT.DAT, at full equilibration), the gas saturation was determined.

\section{b. Fluid-fluid mixing ("Coolbrew" calculations)}

The study first considered the mixing of aqueous solution into a high temperature reservoir with enthalpy constraint scenario (Reeds et al. [11]). CHILLER computed an enthalpy balance between the boiling solution and the mixer solution. The change of composition of the system (TOTAL MOLES was calculated as TOTAL MOLES + STEP INCREM * MIXER TOTAL MOLES) while the total current enthalpy of the system was also changed from ENTH to ENTH + STEP INCREM * MIXER TOTAL MOLES * ENTHW (enthalpy of the mixer solution). The mixing first resulted in the condensation of the gas phase at a constant temperature. Just like in the boiling evaluation, oversaturated minerals as read out in SOLVEQ were suppressed. According to Reeds et $a l$. [11] once all the gas phase were condensed, CHILLER proceeded in computing fluid-fluid mixing and temperature change by setting TEMPC to a non-zero value. This allowed CHILLER to titrate a mixer solution of composition given by mixer total moles into the current solution of composition given by total moles. The composition of the mixer solution was in moles, except for water, mixer total moles, which were in kilograms.

\section{c. Water-rock interaction (MINSOLV option)}

The water-rock interaction option in CHILLER option was enabled with MINSOLV being set to a non-zero value and allowing $\mathrm{SiO}_{2}, \mathrm{Fe}_{2} \mathrm{O}_{3}, \mathrm{FeO}, \mathrm{MgO}, \mathrm{CaO}, \mathrm{Na}_{2} \mathrm{O}, \mathrm{FeS}$ and $\mathrm{NaCl}$ as the reactants. The CHILLER then read the names and amounts of reactants in the CHIMRUN file and their stoichiometries CHILLER from the MINOX data file (Reeds et al. [11]). At the start of a reaction calculation, the total mixer was set to zero while the composition of the system changed from TOTAL MOLES to TOTAL MOLES + STEP INCREM * WTPC $* 0.01 * \mathrm{spec} /$ mwox, where spec is the molar amount of a given component species in the reactant NOMOX, and mwox is the molecular weight of reactant NOMOX. For increments in moles, total moles are changed to TOTAL MOLES + STEP INCREM * WTPC * $0.01 *$ spec.

\subsubsection{Evaluation of Depth of Gas Breakout or Bubble Point}

Gas breakout or two-phase conditions occurs at the depth at which the gas pressure plus water pressure exceeds the total pressure i.e., bubble point depth (Haizlip et al. [7]). In this case, the gas pressure is given in the output files of CHIM programme whereas the water pressures were estimated using steam tables as follows:

$$
\begin{aligned}
& \mathrm{P}_{\text {liq }}=\mathrm{P}_{\text {water }} \text { atsat } \mathrm{T} \\
& \mathrm{P}_{\text {tot }}=\mathrm{P}_{\text {gas }}+\mathrm{P}_{\text {liq }}
\end{aligned}
$$

where $\mathrm{P}_{\text {liq }}=$ pressure of the liquid phase in the well;

$\mathrm{P}_{\text {water }}$ atsat $=$ pressure of the saturated water at given temperature, $\mathrm{T}=$ temperature in kelvin;

$\mathrm{P}_{\text {gas }}=$ pressure of the gas phase in the well, $\mathrm{P}_{\text {tot }}=$ total pressure.

The temperature values were taken from the SOLVEQ output files and were assigned to the major feed zones as determined from the downhole temperature and pressure profiles of each well as shown in Table 4.

\section{Results}

The results are categorized into two parts. Part one presents the evaluation of the equilibrium states of the fluids in the wells considered whereas part 2 details the processes leading to gas evolution. These results are in form of gas pressure (bars) vs temperature graphs.

\subsection{The Equilibrium State of the Fluids}

The $\log \mathrm{H}_{2}$ vs temperature curve (Figure 8) is defined by Equation 5, 6, 7 and 8. The plotted results show that the study wells closely correlate mineral assemblages in Equation 5 which are pyrrohtite, prehnite, epidote and 


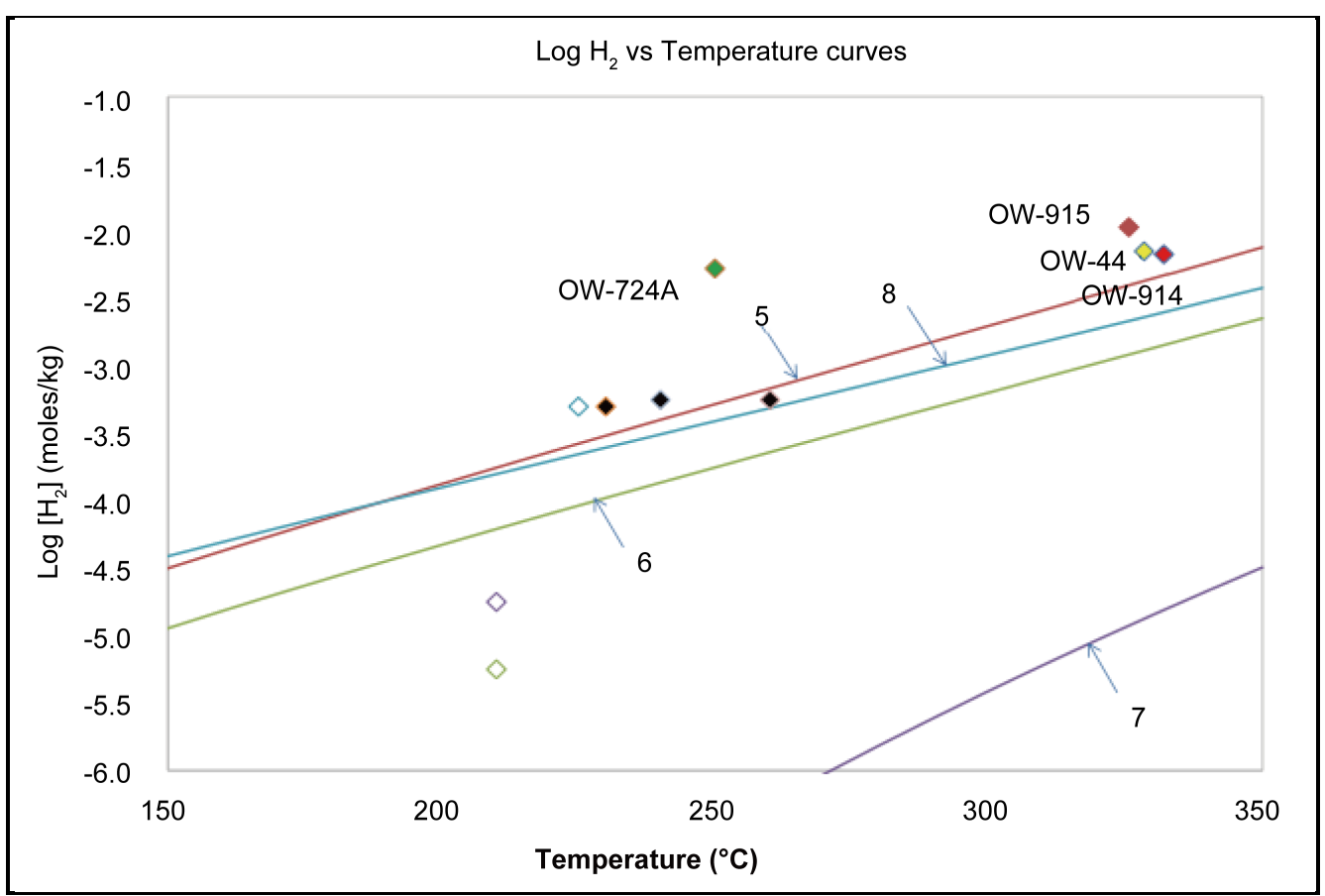

Figure 8. Calculated concentrations of $\mathrm{H}_{2}$ in the total aquifer fluid of wells OW-44, OW-724A, OW-914 and OW-915. White and black symbols are Arnórsson et al. [2] data from Olkaria Domes and Olkaria Central field respectively. The numbers on the curves refer to the reactions in Table 2.

pyrite and 8 with Magnetite, pyrite and pyrrohtite (Table 4). OW-914 appears to be in near equilibrium as it plots close to the equation curve followed by OW-44. OW-915 and OW-724A appear to be non equilibrium as they plot far from the top most equation curve number 5. These results agree with those by Arnórsson et al. [2] where some wells in the field plotted close to the mineral assemblages in 5 and 8 indicating equilibrium with the minerals while others were scattered hence showing non-equilibrium. The gas concentration is low, ranging between -2.0 moles $/ \mathrm{kg}$ in OW-915 and -2.5 moles $/ \mathrm{kg}$ in OW-914, which closely corresponds to a range between -3 moles $/ \mathrm{kg}$ and $-5.5 \mathrm{moles} / \mathrm{kg}$ by (Arnórsson et al. [2]). The $\log \mathrm{H}_{2} \mathrm{~S}$ vs temperature graph has mineral curves for 1, 2, 3 and 4 (Figure 9). The wells plot in the temperature range between $300^{\circ} \mathrm{C}$ and $330^{\circ} \mathrm{C}$. This is with the exception of OW-724A that plots at $250^{\circ} \mathrm{C}$. OW-724A seems to be in equilibrium with mineral assemblage in Equation 1 which comprise of pyrite, pyrrohtite, prehnite and epidote and 4 which has pyrite, pyrrohtite and magnetite. OW-44, on the other hand, with mineral assemblages grossular, pyrite, pyrrohtite, quartz, epidote and wollastonite for Equation 2 and grossular, pyrite, magnetite, quartz, epidote, wollastonite for Equation 3. OW-915 and OW-914 seems to be in non- equilibrium with the mineral assemblage. The results still hold for Arnórsson et al. [2] with the exception of OW-914 which seemed depleted with $\mathrm{H}_{2} \mathrm{~S}$ an indication of steam loss and therefore gas loss.

The $\log \mathrm{CO}_{2}$ graph (Figure 10) is defined by two mineral assemblages 9 and 10. Two wells i.e., OW-914 and OW-915 are in equilibrium with mineral assemblages in Equation 10. OW-44 plots way below mineral assemblage in Equation 9 whereas OW-724A plots above the mineral assemblage in equation 10. This is an indication that OW-724A and OW-44 are in non-equilibrium. The values of concentration also give OW-44 to be having the smallest amount of gas whereas OW-914 has the highest amount. The findings concur with Arnórsson et al. [2] where the Domes Sector had the highest $\mathrm{CO}_{2}$ concentration whose likely cause was the high flux of this gas from the magma heat source.

\subsection{Gas Concentrations and the Reservoir Processes in the Wells}

The reservoir processes considered were boiling, fluid-fluid mixing and titration (Figures 11-14). The plots for OW-44 indicate that boiling is the major process leading to evolution of gases. The gas pressures increased steadily with temperatures, steadily rising from 2.4 and 50 bars. 


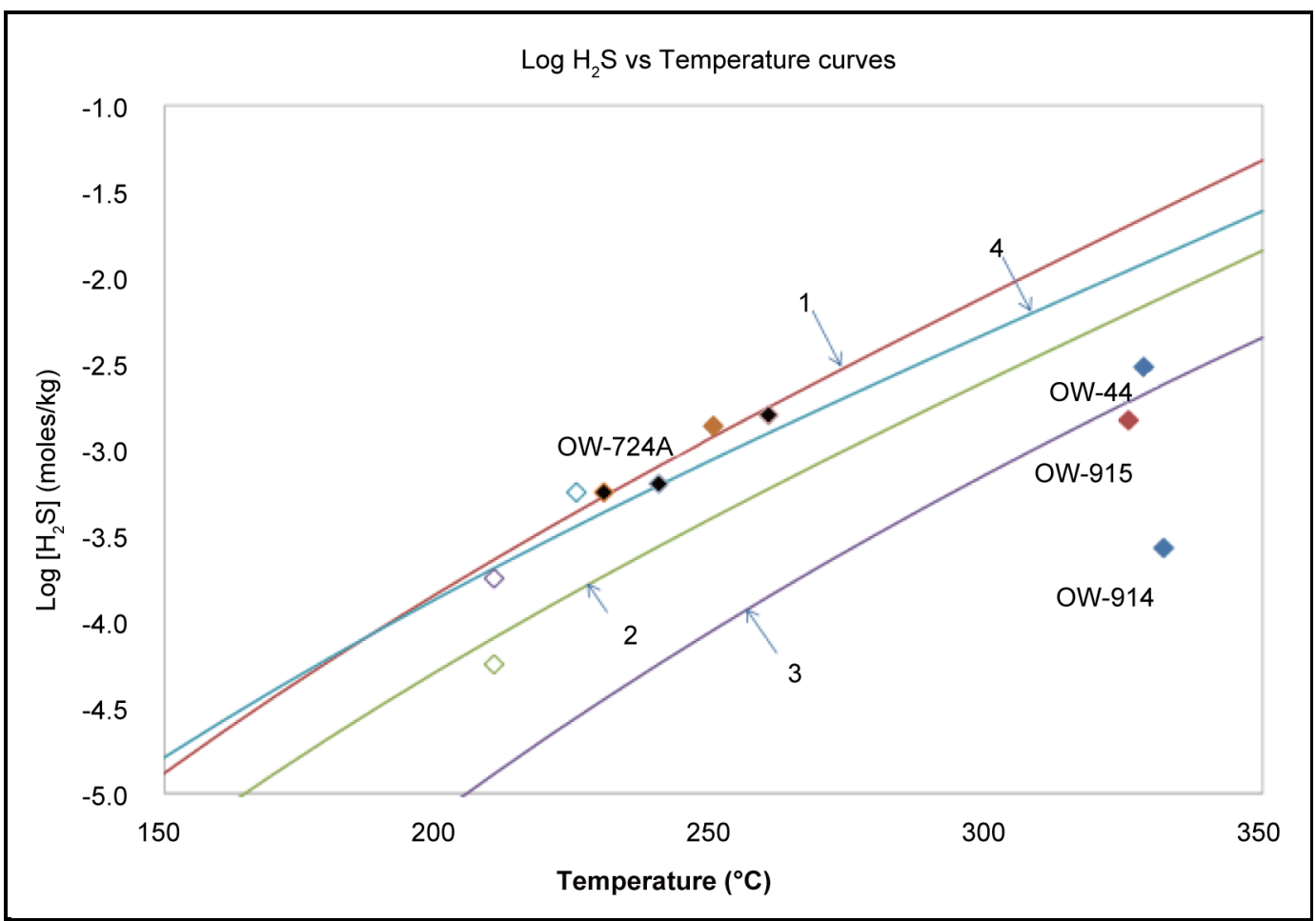

Figure 9. Calculated concentrations of $\mathrm{H}_{2} \mathrm{~S}$ in the total aquifer fluid of wells OW-44, OW-724A, OW-914 and OW-915. White and black symbols are Arnórsson et al. [2] data from Olkaria Domes and Olkaria Central field respectively. The numbers on the curves refer to the reactions in Table 2.

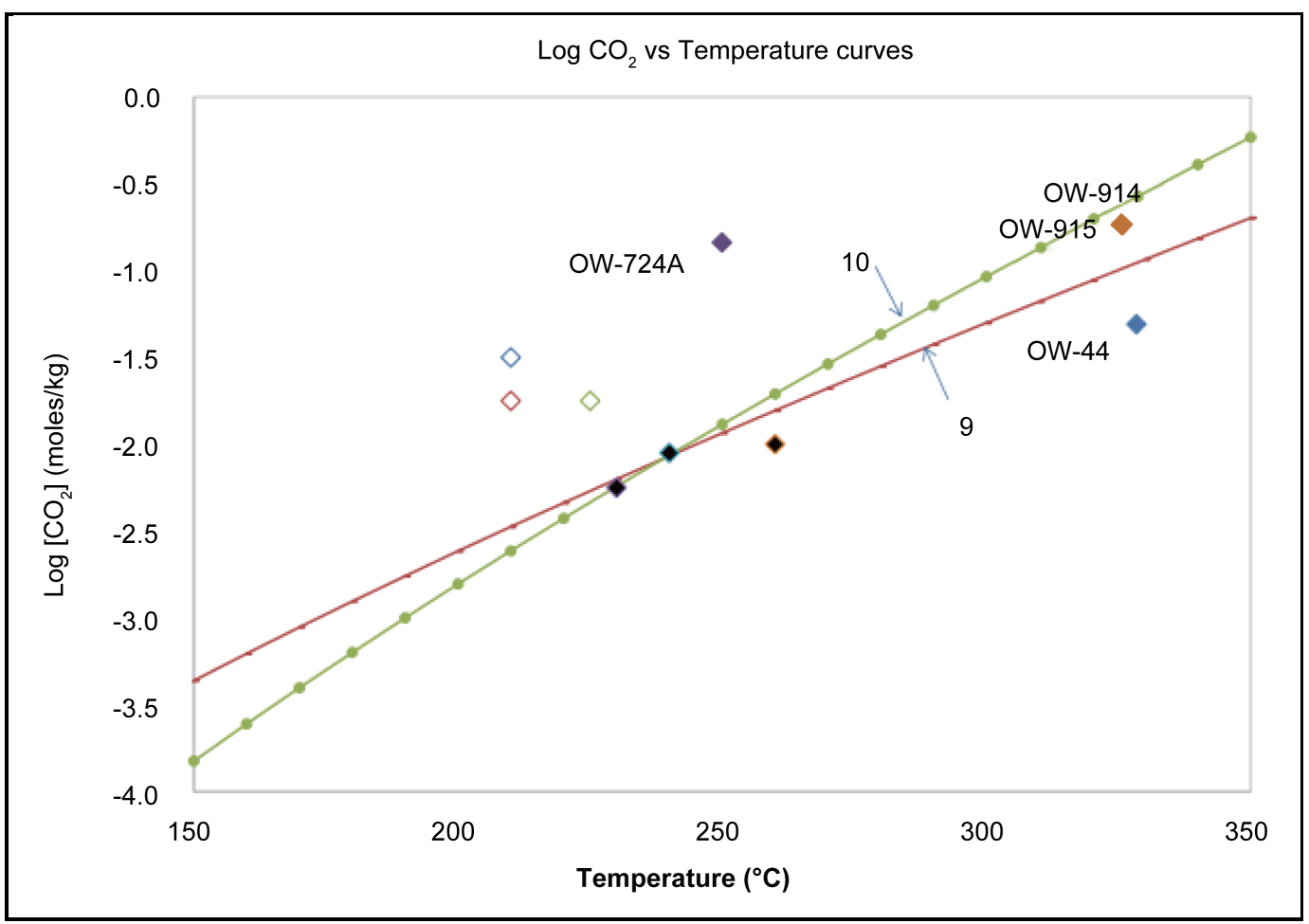

Figure 10. Calculated concentrations of $\mathrm{H}_{2}$ in the total aquifer fluid of wells OW-44, OW-724A, OW-914 and OW-915. White and black symbols are Arnórsson et al. [2] data from Olkaria Domes and Olkaria Central field respectively. The numbers on the curves refer to the reactions in Table 2. 


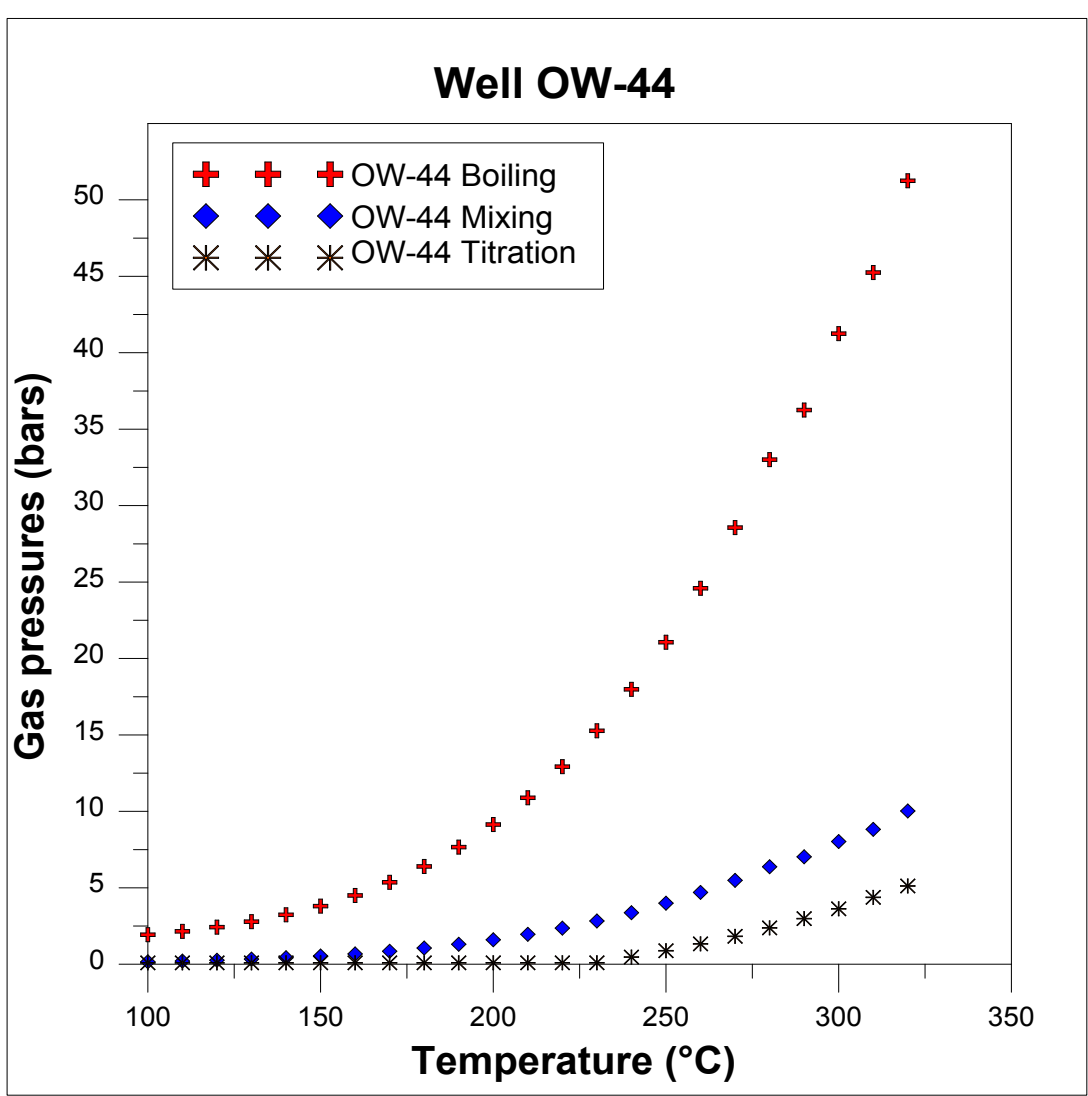

Figure 11. Gas pressures against the reservoir processes in OW-44.

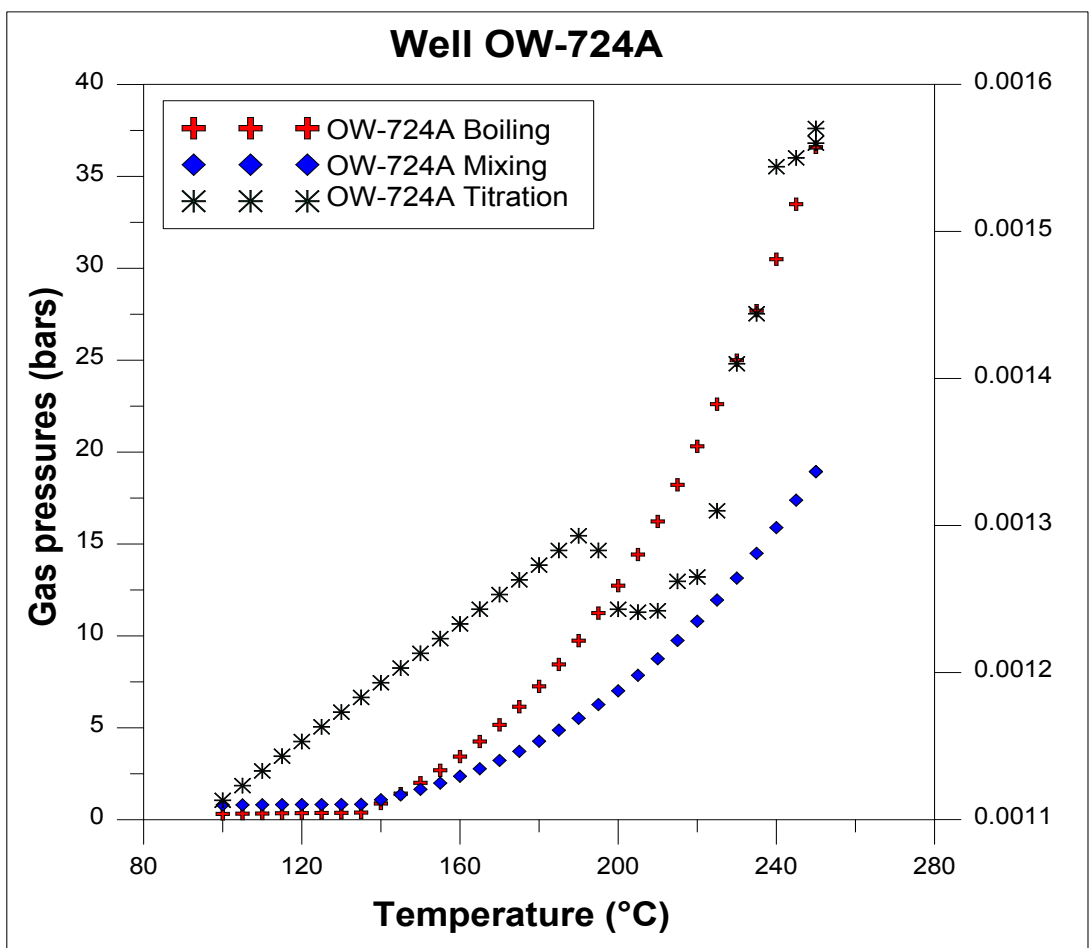

Figure 12. Gas pressures against the reservoir processes in OW-724A. The titration curve has been plotted on the secondary axis. 


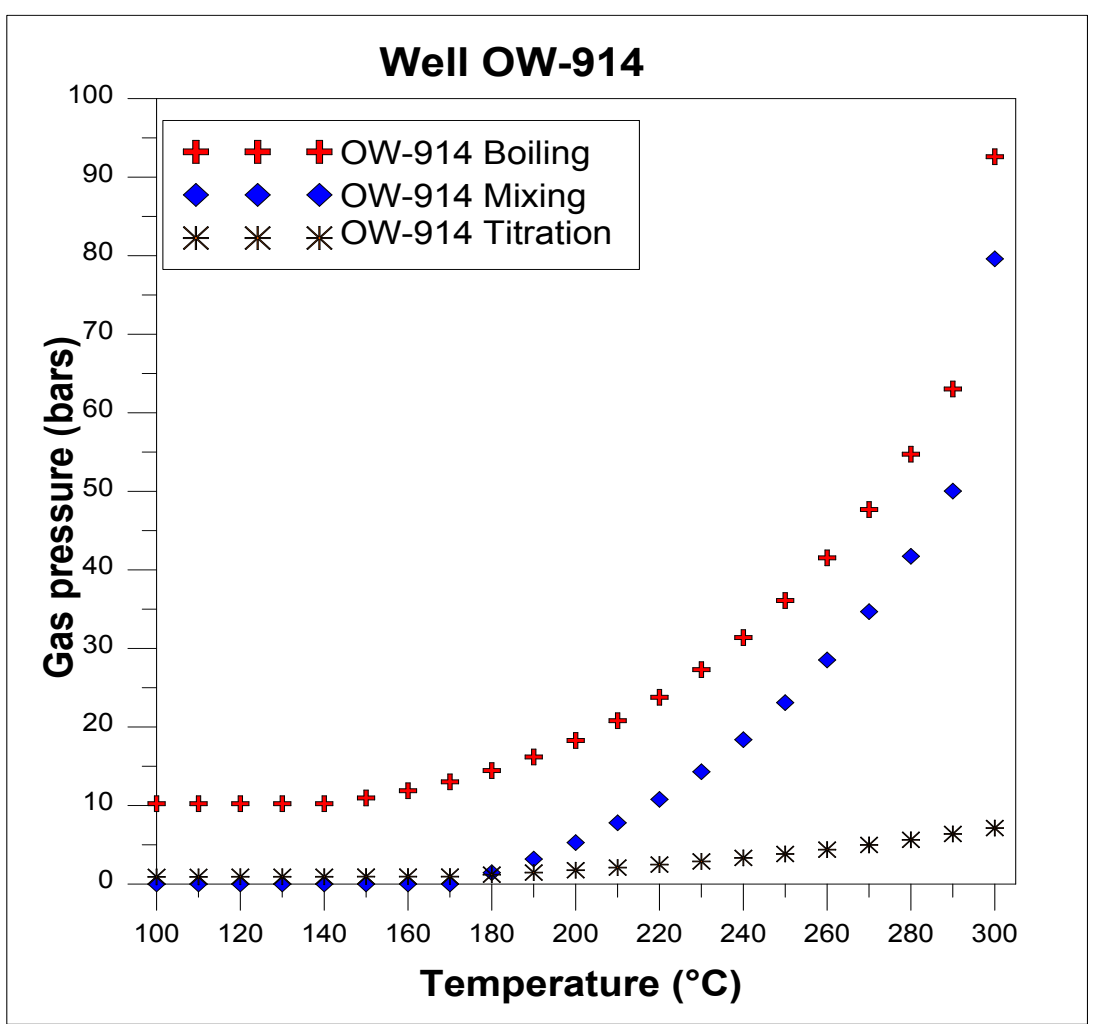

Figure 13. Gas pressures against the reservoir processes in OW-914.

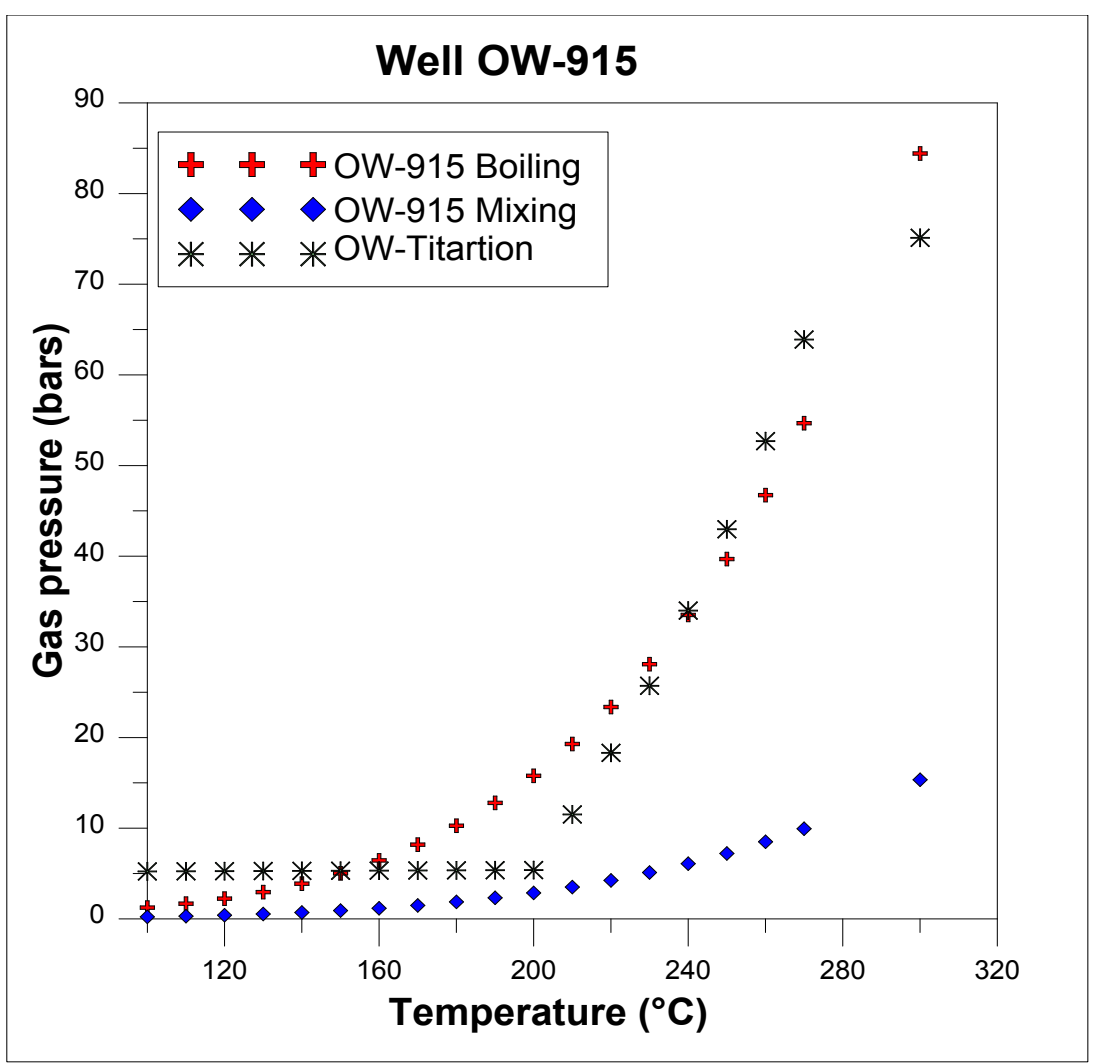

Figure 14. Gas pressures against the reservoir processes in OW-915. 
The mixing process comes in second. Unlike the boiling process, the curve remained levelled up to about $200^{\circ} \mathrm{C}$ before starting to increase. The curve on titration has almost similar trend but lesser values ranging between 0 and 2.4 bars (Figure 11). OW-724A, just like OW-44 has boiling as the major process leading to gas evolution (Figure 12). The graph begins with no change in the gas pressures between $100^{\circ} \mathrm{C}$ and $120^{\circ} \mathrm{C}$ at a gas pressure value of about 0.1 bars before steadily rising to 37 bars. The mixing curve also experiences no change in the gas pressures at start but later increases. The recorded values are lesser, between 0.1 and 17 bars, compared to the boiling processes. The titration process start with a linear increase in the gas pressures up to around $180^{\circ} \mathrm{C}$. The curve however shows a decline in the gas pressures between $180^{\circ} \mathrm{C}$ and $220^{\circ} \mathrm{C}$. OW-914 has its resulting gas pressures due to boiling ranging between 10 and 92 bars (Figure 13). The mixing graphs come in second with values ranging between 0 and 50 bars. The titration curves give almost a zero gradient trend between $100^{\circ} \mathrm{C}$ and $200^{\circ} \mathrm{C}$. This is followed by a slight increase to about 2.5 bars at $300^{\circ} \mathrm{C}$. OW-915 just like OW-914 has its gas pressures due to boiling steadily increasing reaching a high of 85 bars (Figure 14). The mixing curve show a slight increase in the gas pressure with temperature, recording of values between 0 and 10 bars. The titration curve has almost similar trends to OW-724A. The curve start with evidence of an increase in gas pressures to a temperature of $170^{\circ} \mathrm{C}$, levels out to $210^{\circ} \mathrm{C}$ before starting to increase to a high of about 5 bars. The processes comparison curves (Figure 15) indicate boiling processes to be highest in magnitude in OW-914 followed by OW-915, OW-724A. OW-44 has the least amount of gas pressures generated. The mixing process gas evolution, on the other hand seems high in OW-914 followed by OW-724A then OW-915 and lastly OW-44. Titration processes just like the mixing ones are higher in OW-914. OW-915 comes in second followed by OW-44 then OW-724A.

\subsection{Depth of Gas Breakout or Bubble Point}

The measured pressures at the major feed zones give the highest values of 175 bars in OW-44 followed by OW-915 at 150 bars, OW-914 at 100 bars and lastly OW-724A at 90 bars (Table 4). Using steam tables, pressure of the liquid $\left(\mathrm{P}_{\text {liquid }}\right)$ then added to the pressure of the gas $\mathrm{P}_{\text {gas }}$ from CHIM, the totals ranged between 52 bars in OW-44 to 92 bars in the OW-914. From the results, it is identifiable that OW-914 has its total pressure close to the downhole measured one indicating higher chances of gas break out at its major feed zone. OW-44 had the least chances, as its total pressure was way less, at 52 bars compared to 175 bars (measured).

\section{Discussion of the Results}

\subsection{The Equilibrium State of the Fluids}

The current study and that of Arnórsson et al. [2] agree that the $\mathrm{H}_{2}$ and $\mathrm{H}_{2} \mathrm{~S}$ gas concentrations are low in the Olkaria geothermal field. This is confirmed by minor values ranging between -2 to -3.5 moles $/ \mathrm{kg}$ (Figure 8 and Figure 9) indicating that the aquifer vapour fraction is insignificant. Arnórsson et al. [2] attributes these low concentrations to steam loss resulting from the boiling of fluid flowing into these wells. OW-724A plotting way above the mineral assemblage curves in the $\mathrm{H}_{2}$ whereas OW-914 plots way below in the $\mathrm{H}_{2} \mathrm{~S}$ graph. According to Arnórsson et al. [2], non-equilibrium distributions of gas species in a high temperature field like Olkaria arises from processes like boiling, condensation and mixing.

The $\mathrm{CO}_{2}$ plot indicates that the calculated aquifer fluid $\mathrm{CO}_{2}$ concentrations are in equilibrium with mineral assemblages as in the case of OW-914 and OW-915. OW-44, apart from being in non-equilibrium with the mineral assemblages has the least concentration (Figure 10). According to Arnórsson et al. [2], the low $\mathrm{CO}_{2}$ values as in OW-44 are due to insufficient supply of the gas to the fluid to saturate it with calcite. This case therefore reveals that the aquifer fluid $\mathrm{CO}_{2}$ concentration is externally controlled that is, the flux into the geothermal fluid is either from a degassing magma or from the rock with which the geothermal fluid interacts or fumaroles or both. This is opposite with the case of OW-724A which plots above the equilibrium curves. This is an indication that the non-equilibrium in OW-724A maybe arising from a process of volcanic degassing below these areas with minor gas loss compared to OW-44.

\subsection{Gas Concentrations and the Reservoir Processes in the Wells}

The results points to boiling as the major process leading to evolution of gases (Figures 11-14). Simsek et al. [37] while studying the Kizildere geothermal field, Turkey stated that the increase in gases is as a result of 

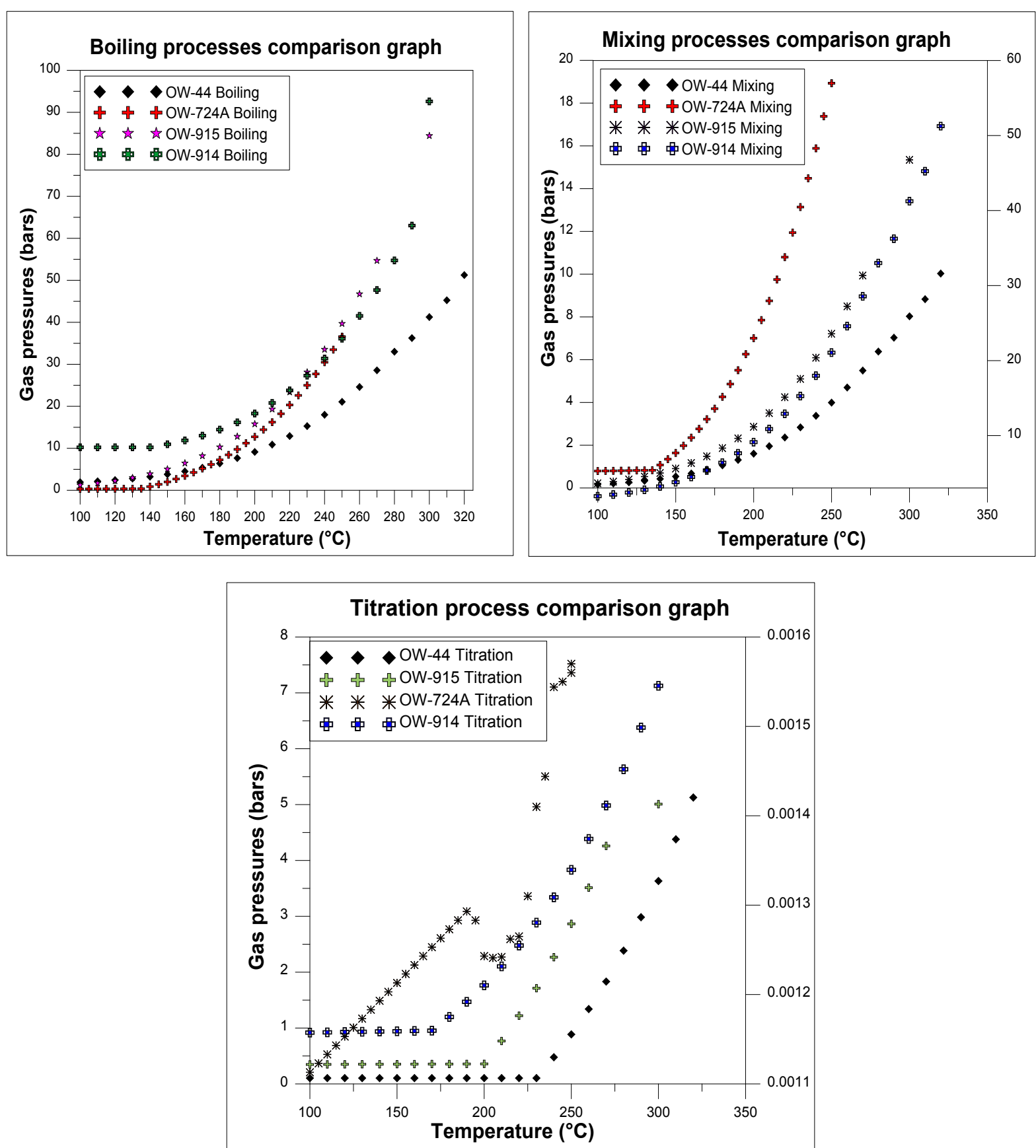

Figure 15. Reaction processes comparison graphs. The titration curve in OW-724A has been plotted on the secondary axis.

Table 4. Showing a comparison between measured and calculated pressures in the main feed zones.

\begin{tabular}{cccccc}
\hline Well name & $\begin{array}{c}\text { Depth of major } \\
\text { feed zone (m) }\end{array}$ & $\begin{array}{c}\text { Measured pressure } \\
\text { (bars) }\end{array}$ & $\begin{array}{c}\text { Calculated liquid } \\
\text { pressure (bars) }\end{array}$ & $\begin{array}{c}\text { Calculated gas } \\
\text { pressure (bars) }\end{array}$ & $\begin{array}{c}\text { Total calculated } \\
\text { pressure (bars) }\end{array}$ \\
\hline OW-44 & 2250 & 175 & 0.105 & 52 & 52 \\
OW-724A & 1700 & 90 & 0.002 & 36 & 36 \\
OW-914 & 1500 & 100 & 0.025 & 92 & 92 \\
OW-915 & 2300 & 150 & 0.035 & 84 & 84 \\
\hline
\end{tabular}


elevated enthalpy resulting from the flow or gravity segregation of water and steam where the steam flow preferentially to the well leaving behind water or enhanced vaporization boiling where there is flow of heat from the rock to the fluid. The former describes a scenario where there is boiling in the area around the well while the later is whenever the water has cooled by adiabatic boiling as a result of the pressure drop leading to generation of steam and gas (Simsek et al. [37]). From the graph, it is notable that the intensity of the processes increases with temperatures in the considered wells. This is so as temperatures act as catalysts for reactions leading to evolution of the gases (Haizlip et al. [7]).

The comparison in the magnitude of this processes in the wells indicate that the impacts of the processes are highest in OW-914 and lowest in OW-44 (Figure 15). This trend in OW-914 is attributed to the high temperature values of about $325^{\circ} \mathrm{C}$ such that chain reactions similar to those discussed in the mixing processes take place. This is further supported by the fact that this well has high injectivity capacity of about $315 \mathrm{lpm} / \mathrm{bar}$, an indication of high permeability of the well. This acts to bring in fluids that in turn react with the mineral assemblages in the aquifer rocks leading to evolution of gases.

OW-44 had the least gas concentrations arising from the considered reservoir processes despite the fact that it has high downhole temperatures of about $300^{\circ} \mathrm{C}$ and considerably high injectivity. Hazil et al. [7] attributes this to loss of gas from the deep fluid due to degassing and near surface boiling. Besides that, $\mathrm{NH}_{3}, \mathrm{H}_{2}$ and $\mathrm{H}_{2} \mathrm{~S}$ can be removed from the steam formed through boiling by processes like wall-rock interactions and solution into steam condensate. Then depending on how far the well is from the recharge zone, gases in the reservoir fluid tend to enter the vapour phase whenever possible (Simsek et al. [37]). Therefore, when boiling sets in, the initial steam formed contains majority of the dissolved gases thus the residual liquid is therefore highly depleted in dissolved gases and later stages of steam separation will contain increasingly lower concentrations of gases. Steam formed in the early stages of boiling is therefore characterized by higher gas content.

\subsection{Depth of Gas Breakout or Bubble Point}

This was meant to determine the potential impacts of the gases on the performance of the wells. The results (Table 3) indicate that likelihood of a gas breakout is highest in OW-914 and least in OW-44. This therefore is an indication that OW-914 is likely to experience calcite scaling at its major feed zone at $1500 \mathrm{~m}$ depth, considering the type of waters feeding the well. This finding agrees with a dynamic survey carried out in OW-914 well in 2014 (Figure 16). The results pointed to a calcite scaling potential in the depths between 1200 and $1800 \mathrm{~m}$. According to Akin et al. [6] due to pressure drop, thermal fluids tend start to boiling and degassing of $\mathrm{CO}_{2}$ as the fluids rise in a wellbore.

When the initial gas bubbles are formed, $\mathrm{CO}_{2}$ exsolution affects the $\mathrm{pH}$ together with the carbonate species leading to the thermal fluid becoming saturated to calcite.

\section{Possible Reservoir Management Options}

Continuous exploitation has tended to increase the concentration of non-condensable gases in the reservoir (Moya and Yock [28]). Moya and Yock [38] add that this in turn need the establishment of a program of detailed monitoring of the non-condensable gases at each well in order to determine the principal causes of the increase, and to select the best injection and production strategies to improve on the existing operating conditions. This study has indicated that the principal cause of the increase in non-condensable gases is pressure decline in the reservoir leading to depressurization boiling. In order to minimize this tendency, two different strategies for the different parts of the Olkaria geothermal field were considered $\left({ }^{\circ} \mathrm{C}\right)$. First, a need for a reinjection programme which will help in increasing the volume of fluids injected in the eastern sector (represented by well OW-44). The immediate response here would be the decrease in the enthalpy of the wells and gases evolution.

For wells around and with similar chemistry like OW-914, two options are applicable. First the management by operating the wells at a minimum flow rate (or even to close them). According to Moya and Sanchez [39] this will enable reduction in the pressure drop and consequently the non-condensable gas evolution due to depressurization boiling. This will also lead to a lowered scaling point and or reduced numbers of work over as demonstrated in Figure 17. The second option will be to consider chemical inhibitors dosing. According to Haizlip et al. [7] successful scale mitigation in the wellbore requires that the inhibitor is injected into the flowing well through capillary tubing at depths $10-50 \mathrm{~m}$ below the estimated gas breakout depth preferably within the casing. The inhibitors act by poisoning the growth of scale. 


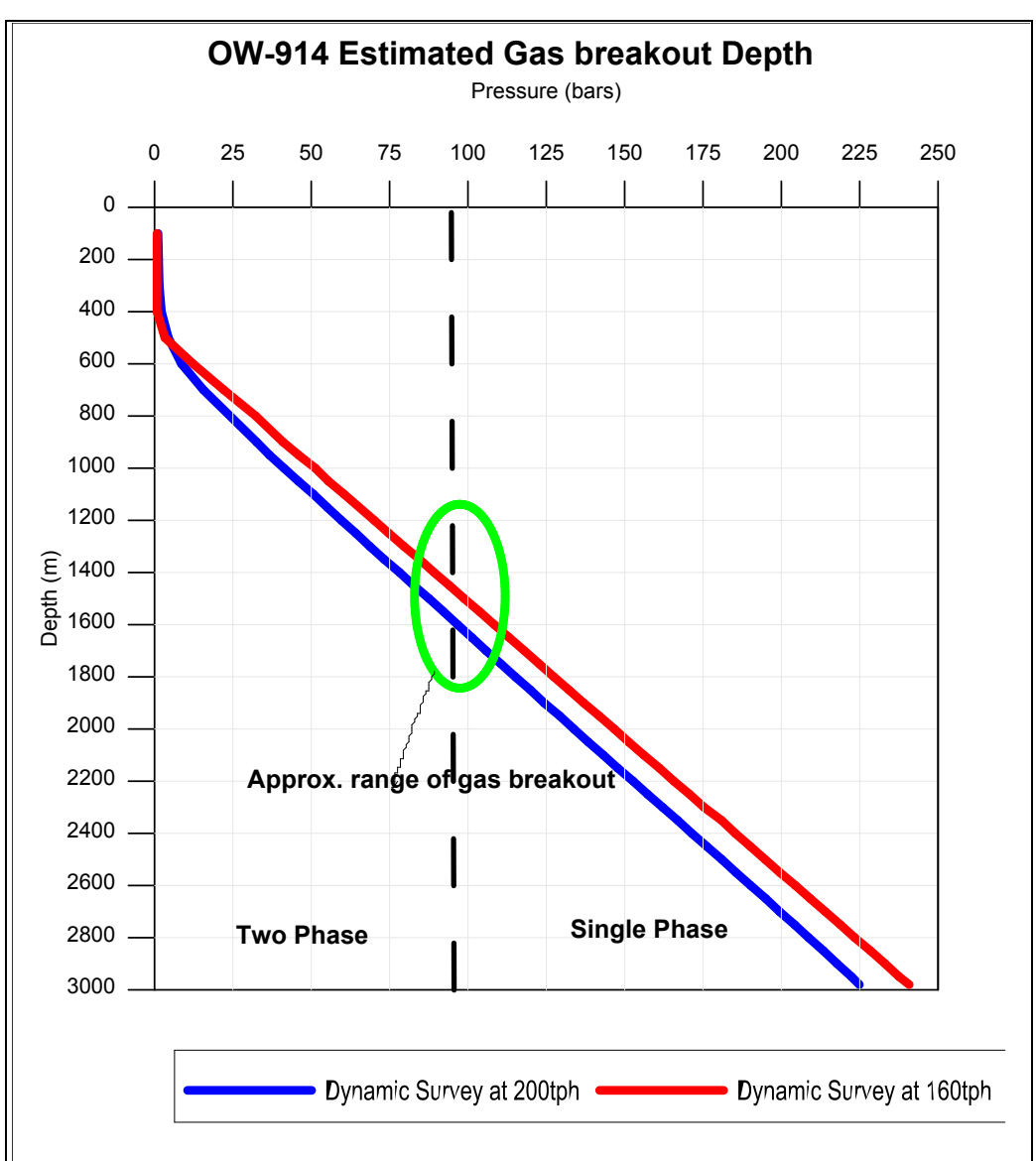

Figure 16. Estimated gas breakout depth in OW-914 from the dynamic surveys.

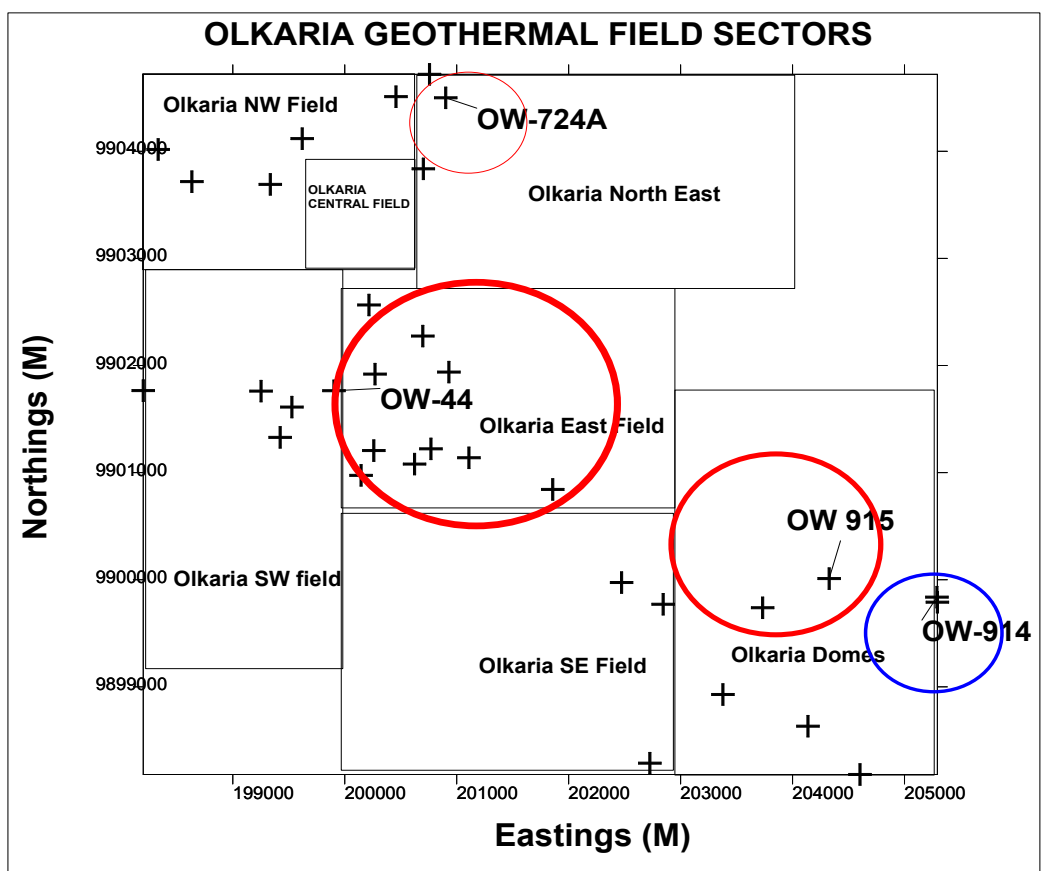

Figure 17. Management options for different parts of the field. Red eclipses for reinjection while the blue one is for reduced flow from wells and inhibition. 


\section{Conclusions}

The study concludes that

- The gas species are not in equilibrium with the mineral assemblages due to processes of boiling, condensation and mixing. This is with the exceptions of $\mathrm{CO}_{2}$ in OW-914 and OW-915 which are in equilibrium with mineral assemblages in Equation 10.

- The CHILLER evaluation shows boiling as the major process leading to the evolution of gases.

- OW-44 had the least gas concentrations arising from the considered reservoir processes due to degassing and near surface boiling. Besides the removal of $\mathrm{NH}_{3}, \mathrm{H}_{2}$ and $\mathrm{H}_{2} \mathrm{~S}$ are through the reaction with steam condensate.

- Gas breakout is most likely in OW-914 and least in OW-44.

- Different strategies for the management of different parts of the Olkaria geothermal field can be used. That is increased volume of fluids injected in the eastern sector (represented by well OW-44), while around OW914 it is to be managed by operating the wells at a minimum flow rate (or even to close them) or the use of chemical inhibitors.

\section{References}

[1] West Japan Engineering Consultants Inc. (2009) The Olkaria Optimization Study (Phase II)—Final Reservoir Analysis Report. West Japan Engineering Consultants Inc., Fukuoka, 301 p.

[2] Arnórsson, S., Angcoy, E.C., Bjarnason, J.Ö., Giroud, N., Gunnarsson, I., Kaasalainen, H., Karingithi, C. and Stefánsson, A. (2010) Gas Chemistry of Volcanic Geothermal Systems. Proceedings of the World Geothermal Congress 2010, Bali, 25-29 April 2010, 12 p.

[3] Angcoy, E.C. (2010) Geochemical Modeling of the High-Temperature Mahanagdong Geothermal Field, Leyte, Philippines. MSc Thesis, UNU-GTP, Report 1, University of Iceland, Reykjavík, 71 p.

[4] Giroud, N. and Arnórsson, S. (2005) Estimation of Long-Term $\mathrm{CO}_{2}$ and $\mathrm{H}_{2} \mathrm{~S}$ Release during Operation of Geothermal Power Plants. Proceedings of the World Geothermal Congress 2005, Antalya, 24-29 April 2005, 6 p.

[5] Karingithi, C.W. (2002) Hydrothermal Mineral Buffers Controlling Reactive Gases Concentration in the Greater Olkaria Geothermal System, Kenya. MSc Thesis, UNU-GTP, Report 2, University of Iceland, Reykjavík, 51 p.

[6] Akin, T., Guney, A. and Kargi, H. (2015) Modeling of Calcite Scaling and Estimation of Gas Breakout Depth in a Geothermal Well by Using PHREEQC. Proceedings of the 40th Workshop on Geothermal Reservoir Engineering, Stanford, 26-28 January 2015, 8 p.

[7] Haizlip, J.R., Guney, A., Tut Haklidir, F.S. and Garg, S.K. (2012) The Impact of High Non Condensable Gas Concentrations on Well Performance-Kizildere Geothermal Reservoir, Turkey. Proceedings of the 37th Workshop on Geothermal Reservoir Engineering, Stanford, 30 January-1 February 2012, 6 p.

[8] Gudmundsson, B.T. and Arnórsson, S. (2002) Geochemical Monitoring of the Krafla and Námafjall Geothermal Areas, N-Iceland. Geothermics, 31, 195-243. http://dx.doi.org/10.1016/S0375-6505(01)00022-0

[9] Ármannsson, H. (2003) $\mathrm{CO}_{2}$ Emission from Geothermal Plants. Proceedings of the International Conference on Multiple Integrated Uses of Geothermal Resources, Reykjavik, 14-17 September 2003, 56-62.

[10] Reed, M.H., Spycher, N.F. and Palandri, J. (2012) SOLVEQ-XPT: A Computer Program for Computing AqueousMineral-Gas Equilibria. University of Oregon, Department of Geological Sciences, Eugene, 43 p.

[11] Reed, M.H., Spycher, N.F. and Palandri, J. (2012) Users Guide for CHIM-XPT: A Program for Computing Reaction Processes in Aqueous-Mineral-Gas Systems and MINTAB Guide (Ver 2.43). University of Oregon, Department of Geological Sciences, Eugene, 73 p.

[12] Bienkowski, R., Torres-Alvarado, I.S. and Hinderer, M. (2003) Genese hochsaurer Fluide im Geothermalfeld von Los Humeros, Zentral-Mexiko. MSc Thesis, Institut für Angewandte Geowissenschaften, Technische Universität Darmstadt, Diplomarbeit, $89 \mathrm{p}$.

[13] Lagat, J., Arnórsson, S. and Franzson, H. (2005) Geology, Hydrothermal Alteration and Fluid Inclusion Studies of Olkaria Domes Geothermal Field, Kenya. Proceedings of the World Geothermal Congress 2005, Antalya, 24-29 April 2005,14 p.

[14] KenGen (1999) Conceptualized Model of the Olkaria Geothermal Field. Internal Report No. 10, Kenya Electricity Generating Company Ltd. (Ken Gen), Nairobi, 46 p.

[15] Naylor, W.I. (1972) The Geology of the Eburru and Olkaria Geothermal Projects. United Nations Development Programme, Report No. 01, $52 \mathrm{p}$.

[16] Virkir (1980) Geothermal Development at Olkaria. Virkir Consulting Group, Report No. 09 Prepared for Kenya Power 
Company, $40 \mathrm{p}$.

[17] Clarke, M.C.G., Woodhall, D.G., Allen, D. and Darling, G. (1990) Geological, Volcanological and Hydogeological Controls of the Occurrence of Geothermal Activity in the Area Surrounding Lake Naivasha, Kenya. Report, Ministry of Energy, Nairobi, $138 \mathrm{p}$.

[18] Mungania, J. (1992) Preliminary Field Report on Geology of Olkaria Volcanic Complex with Emphasis on Domes Area Field Investigations. Internal Report No. 11, Kenya Power Company, Nairobi, 37 p.

[19] Omenda, P.A. (2000) Anatectic Origin for Comendite in Olkaria Geothermal Field, Kenya Rift; Geochemical Evidence for Syenitic Protholith. African Journal of Science and Technology, 1, 39-47.

[20] Shackleton, R.M. (1986) Precambrian Collision Tectonics in Africa. In: Coward, M.P. and Ries, A.C., Eds., Collision Tectonics, Special Publications Vol. 19, Geological Society, London, 329-349. http://dx.doi.org/10.1144/gsl.sp.1986.019.01.19

[21] Smith, M. and Mosley, P. (1993) Crustal Heterogeneity and Basement Influence on the Development of the Kenya Rift, East Africa. Tectonics, 12, 591-606. http://dx.doi.org/10.1029/92TC01710

[22] Omenda, P.A. (1994) Geological Control on the Reservoir Characteristics of Olkaria West Geothermal Field, Kenya. Proceedings of the 19th Workshop on Geothermal Reservoir Engineering, Stanford, 18-20 January 1994, 125-129.

[23] Thompson, A.O. and Dodson, R.G. (1963) Geology of the Naivasha Area. Geological Survey Kenya, Report No. 55, $88 \mathrm{p}$.

[24] Ogoso-Odongo, M.E. (1986) Geology of Olkaria Geothermal Field. Geothermics, 15, 741-748. http://dx.doi.org/10.1016/0375-6505(86)90087-8

[25] Ofwona, C.O. (2002) A Reservoir Study of Olkaria East Geothermal System, Kenya. MSc Thesis, UNU-GTP, University of Iceland, Reykjavík, Report No. 1, 74 p.

[26] Ambusso, W.J. and Ouma, P.A. (1991) Thermodynamic and Permeability Structure of Olkaria Northeast Field: Olkaria Fault. Geothermal Resource Council Transactions, 15, 237-242.

[27] Ouma, P.A. (1999) Reservoir Engineering Report for Olkaria Domes Field. Internal Report No. 14, Kenya Electricity Generating Company Ltd. (Ken Gen), Nairobi, 54 p.

[28] Karingithi, C.W. (2000) Geochemical Characteristics of the Greater Olkaria Geothermal Field, Kenya. Report 9 in: Geothermal Training in Iceland 2000. UNU-GTP, Reykjavík, 165-188.

[29] Wambugu, J.M. (1995) Geochemical Update of Olkaria West Geothermal Field. Internal Report No. 5, Kenya Power Company Ltd., Nairobi, 40 p.

[30] KenGen (2014) Revised Geochemical Model of the Olkaria Geothermal Field. Internal Report No. 1, Kenya Electricity Generating Company Ltd. (Ken Gen), Nairobi, 23 p.

[31] Wamalwa, R., Nyamai, C.M., Ambusso, W. and Mulwa, J. (2014) Structural Controls on the Chemistry and Output of the Wells in the Olkaria Geothermal Field, Rift Valley, Kenya. Proceedings of the 5th African Rift Geothermal (ARGeo-C5), Arusha, 27 October-2 November 2014, 11 p.

[32] Arnórsson, S., Bjarnason, J.Ö., Giroud, N., Gunnarsson, I. and Stefánsson, A. (2006) Sampling and Analysis of Geothermal Fluids. Geofluids, 6, 203-216. http://dx.doi.org/10.1111/j.1468-8123.2006.00147.x

[33] Stefánsson, A., Arnórsson, S. and Bjarnason, J.Ö. (2007) Fluid-Fluid Interaction in Geothermal Systems. Reviews in Mineralogy \& Geochemistry, 65, 259-312. http://dx.doi.org/10.2138/rmg.2007.65.9

[34] Holland, T.J.B. and Powell, R. (1990) An Enlarged and Updated Internally Consistent Thermodynamic Dataset with Uncertainties and Correlations: The System $\mathrm{K}_{2} \mathrm{O}-\mathrm{Na}_{2} \mathrm{O}-\mathrm{CaO}-\mathrm{MgO}-\mathrm{MnO}-\mathrm{FeO}-\mathrm{Fe}_{2} \mathrm{O}_{3}-\mathrm{Al}_{2} \mathrm{O}_{3}-\mathrm{TiO}_{2}-\mathrm{SiO}_{2}-\mathrm{C}-\mathrm{H}_{2}-\mathrm{O}_{2}$. Journal of Metamorphic Geology, 8, 89-124. http://dx.doi.org/10.1111/j.1525-1314.1990.tb00458.x

[35] Robie, R.A. and Hemingway, B.S. (1995) Thermodynamic Properties of Minerals and Related Substances at 298.15 K and 1 Bar (105 Pascals) Pressures and at Higher Temperatures. US Geological Survey Bulletin, 2131, $461 \mathrm{p}$.

[36] Fernandez-Prini, R., Alvarez, J.L. and Harvey, A.H. (2003) Henry's Constants and Vapour-Liquid Distribution Constants for Gaseous Solutes in $\mathrm{H}_{2} \mathrm{O}$ and $\mathrm{D}_{2} \mathrm{O}$ at High Temperatures. Journal of Physical and Chemical Reference Data, 32, 903-916. http://dx.doi.org/10.1063/1.1564818

[37] Simsek, S., Parlaktuna, M. and Akın, S. (2009) Data Gathering and Evaluation of Kizildere Geothermal Field. Report for Zorlu Energy, 13 p.

[38] Moya, P. and Yock, A. (2005) First Eleven Years of Exploitation at the Miravalles Geothermal Field. Proceedings of the 30th Workshop on Geothermal Reservoir Engineering, Stanford, 31 January-2 February 2005, 8 p.

[39] Moya, P. and Sánchez, E. (2005) Non-Condensable Gases at the Miravalles Geothermal Field. Proceedings of the 30th Workshop on Geothermal Reservoir Engineering, Stanford, 31 January-2 February 2005, 11 p. 